\title{
HÁMORI BALÁZS
}

\section{A figyelem ökonómiája}

\section{A vevők meghódításának új módszerei és csatornái}

A többletgazdaságban a termelöknek/szolgáltatóknak/kereskedőknek törekedniük kell a vevők meghódítására. Ennek költségei, amelyek csak igen csekély többlethasznot hoznak a fogyasztók számára, az idők során folyamatosan nőttek. Az információgazdaságra jellemző szolgáltatások - különösen a szellemi javak - esetében meghatározó tényező a fogyasztásukhoz, felhasználásukhoz szükséges figyelem. A személyes szolgáltatások mindig is nagy figyelmet igényeltek. A termelés és a szolgáltatások testreszabásával, a közvetlen interakciók sürüsödésével és a tranzakciók virtuális térbe helyeződésével szükségszerüen nö a gazdasági folyamatok figyelemigénye. Az immateriális javak előállítói számára a partnerek figyelmének a lekötése gyakran a legfontosabb versenytényező. Nemcsak a vevők figyelmének, hanem az eladók figyelmének a jelentősége is nő: a figyelem mint eladói „szolgáltatás" az értékteremtés forrásává válik. Radikálisan változnak a figyelem felkeltésének a módszerei is. A figyelem „tőzsdéje” a társadalmi nyilvánosság, és az internet akár a figyelem sajátos világpiacaként is felfogható. Dicsőség, kiválóság és presztízs a felhalmozott figyelem megnyilvánulási formái. Azaz, a figyelem tőke-, értékmegőrző és -gyarapító funkcióval rendelkezik, noha azt nem lehet minden további nélkül összevetni a pénz hasonló mechanizmusaival. A figyelem ökonómiája ma még gyerekcipőben jár, ám nem kétséges, hogy az információgazdaság tranzakciós terének a vizsgálatakor kiemelten kell figyelni a figyelemre. ${ }^{*}$

Journal of Economic Literature (JEL) kód: D21, D80, E71, M31, M37.

* E cikk részben támaszkodik az MTA doktori disszertációm hasonló témakörben íródott fejezetére. Hálás vagyok †Szabó Katalinnak, aki a tanulmány korai változatának első olvasójaként és kritikusaként megjegyzéseivel új irányt szabott akkori gondolkodásomnak, okfejtésemnek. Ugyancsak köszönettel tartozom kollégáimnak és barátaimnak, Bőgel Györgynek, Derecskei Anitának, Tóth Lászlónak, akik lényeges észrevételekkel, javaslatokkal segítették a munka megszületését. Továbbá Ertl Antalnak, aki megjegyzéseivel, egyes statisztikai anyagok gyüjtésével támogatta az írás elkészültét. Ugyancsak köszönöm hazai és külföldi hallgatóimnak a Budapesti Corvinus Egyetemen és a Szegedi Tudományegyetemen, hogy a vitákban értő véleményükkel nyújtottak érdemleges segítséget.

Hámori Balázs professor emeritus, BCE Összehasonlító és Intézményi Gazdaságtan Tanszék (e-mail:

bhamori@uni-corvinus.hu).

A kézirat első változata 2020. december 10-én érkezett szerkesztőségünkbe.

DOI: http://dx.doi.org/10.18414/KSZ.2021.1.96 
Kiindulásként megemlítjük, hogy alaptételként kezeljük, hogy a többletgazdaságban - a kínálati túlsúlyból következően - a termelőknek/eladóknak törekedniük kell a vevők meghódítására, és folyamatosan, a kapitalizmus minden korszakában és érettségi fokán erőfeszítéseket kell tenniük a vevők megnyerésére. Az ezzel kapcsolatos költségek folyamatosan növekedtek, és mind nagyobb súlyt képviseltek a költségszerkezetben, amint az a fél évszázadot átfogó 1. ábrán is látható.

\section{1. ábra}

A vállalati költségszerkezet átalakulása, 1945-1995 (százalék)

1945

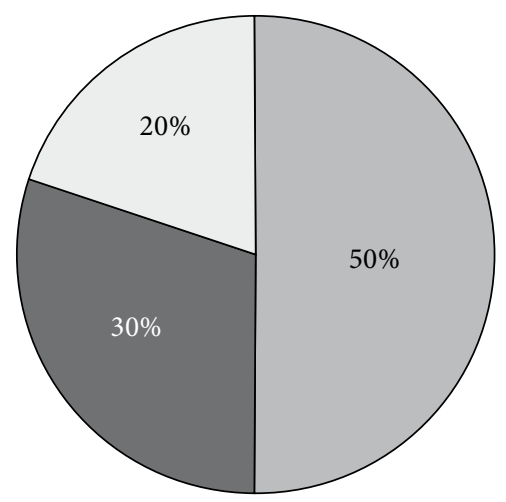

Forrás: Weber [2002] 706. o.
1995

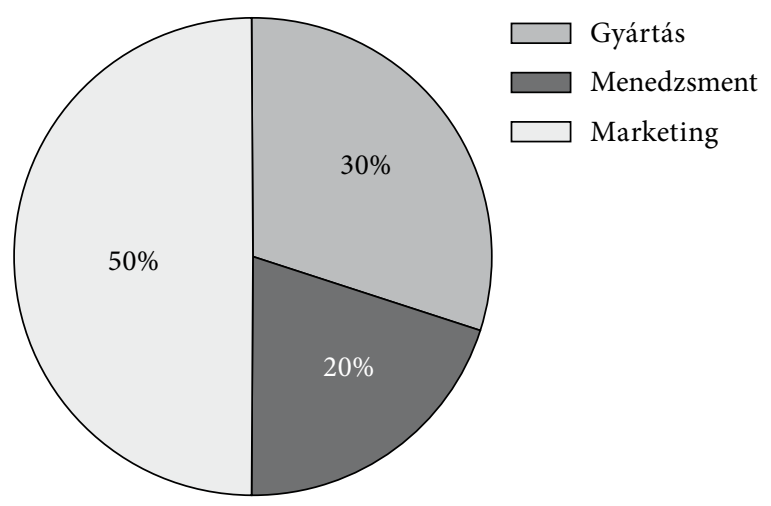

Piaci részesedésük növelése érdekében a vállalatoknak meg kell győzniük a megcélzott vásárlói kört termékeik/szolgáltatásaik kiválóságáról, igazolniuk kell előnyeiket a más cégek termékeihez képest. A piac megdolgozásával kapcsolatos müveletek során egy sajátos szűkös eröforrást használnak fel: a figyelmet - elsősorban a potenciális vevő figyelmét.

\section{Figyelem a többletgazdaságban}

A vevők figyelmére természetesen azért is szükség van, hogy valós információkhoz jussanak a termékek/szolgáltatások beszerzési lehetőségeiről és használatáról. Ahhoz például, hogy a fogyasztó rendeltetésszerüen használjon egy háztartási gépet, tudnia kell, hogy egyáltalán hol és milyen feltételekkel juthat a géphez, figyelmesen kell tanulmányoznia a gép műszaki tulajdonságait, a használati útmutatóját stb.

\section{Figyelem a hagyományos termékekre irányuló tranzakciókban}

A tranzakciót kísérő, az eladótól a vevő felé áramló, a vevő figyelmére számító információk azonban már az információs kort megelöző indusztriális korban sem merültek ki a tárgyszerü tájékoztatásban. A kínálati többlet következtében intenzív 
reklámtevékenység folyt, s a reklámok is igénylik a vevők figyelmét, és ez nem is lehet másképp a többletgazdaságban.

„A rendszer veleszületett és gyógyíthatatlan bajaival együtt kell élni. Tudomást kell venni arról, hogy ahol többletgazdaság van, ott hatalmassá duzzadhatnak a vevőre váró kereskedelmi készletek, ott hirdetésözön van, ott a közbeszerzési eljárások során gyakran felbukkan a korrupció, és így tovább. [...] Sok igazság van abban, hogy az eladók a hirdetéseikkel nemcsak tájékoztatni akarják a vevőket (ami egyértelmüen hasznos információközlés), de megpróbálják manipulálni is őket. [...] Aki a többletgazdaságot - más okok miatt - elönyösebbnek tartja a hiánygazdaságnál, annak tudomásul kell vennie, hogy menthetetlenül hozzátartozik a hirdetésözön, a sokszor korrekt, de nemritkán félrevezető reklámhadjáratok, a vevőket magukhoz csalogató eladási trükkök." (Kornai [2011] 148., 157. o.; kiemelés tőlem - H. B.)

Még olyan merőben fizikai termékeket forgalmazó cégek esetében is, mint az élelmiszergazdaságban működő vállalatok, a marketingköltségek dominálnak az élelmiszerárak kialakításakor a kiskereskedelemben. A termelési költségeket folyamatosan leszorítják, miközben a marketingköltségek növekednek. Az Egyesült Államokban 1950 és 1999 között az élelmiszerárakban a termelés költségei (farm value) átlagosan körülbelül a teljes költségek 20 százalékára (!) csökkentek. Csak a csomagolási költségek - amelyek a marketingköltségeknek egy kis hányadát jelentik - a teljes költség 8 százalékát tették ki. ${ }^{1}$ A marketingre fordított kiadások sokszor gyorsabban nőttek, mint a termelési költségek a hazai élelmiszereknél. Más ágazatban is, például a gyógyszeriparban, a termelési költségeket majd kétszeresen haladják meg a marketingköltségek (2. ábra). ${ }^{2}$

\section{2. ábra}

A gyógyszergyártás költségszerkezete az Egyesült Államokban, 2011-2018

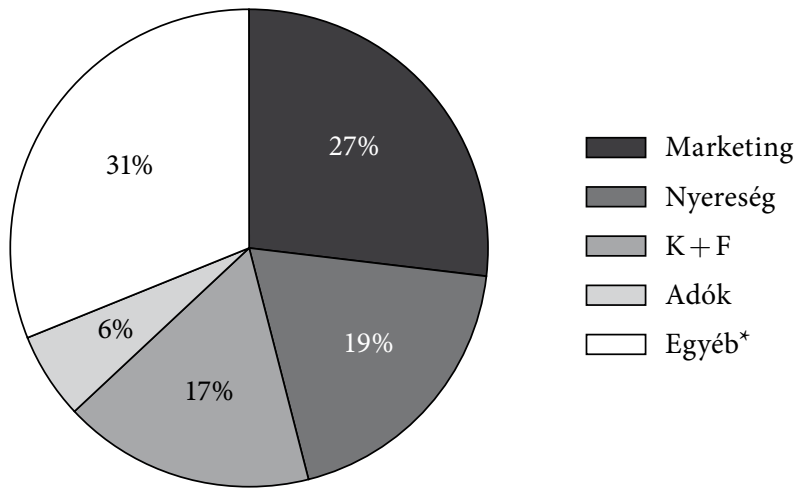

* Követlen gyártási, raktározási, logisztikai és általános költségek.

Forrás: Belk-Belk [2020].

${ }^{1}$ Az adatok forrása: Cost of Food (Kinsey-Weaver [2003] 462-465. o.).

${ }^{2}$ Érdekes (esetleges) fordulat képét vetíti ugyanakkor elöre a legnagyobb gyógyszergyárak vezetőinek a meghallgatása az árakkal és a költségekkel kapcsolatban az Egyesült Államok szenátusának pénzügyi bizottságában 2019-ben. Míg a 2014 és 2018 között nyilvánosságra került adatok a marketingköltségek dominanciáját mutatták a K + F-költségekkel szemben, addig az említett meghallgatáson a kilenc legnagyobb gyógyszeripari cég közül hét nyilatkozott úgy, hogy a $\mathrm{K}+\mathrm{F}-\mathrm{költségei} \mathrm{maga-}$ sabbak, mint a marketing- és az értékesítési költségek (ásd erről részletesen Brennan [2019]). 
A fogyasztók/kliensek figyelmének a lekötését szolgáló költségek tehát még a fizikai javak termelői számára is vetekszenek a termelésre fordítottakkal. Ez nem független attól, hogy a valódi értéket nem a termék anyagi teste, hanem a benne sürüsödött szellemi alkotórészek adják.

\section{A figyelem iránti növekvő igény a dematerializálódó gazdaságban}

Még ennél is egyértelműbb a helyzet a megfoghatatlan, digitális formában létező szellemi termékek, illetve a szolgáltatások nagy részénél. E termékek esetében a vevő-eladó viszony sokkal kiegyensúlyozatlanabb, mint a fizikai termékek esetében. Míg a digitalizált szellemi termékeket kínálók intenzíven versenyeznek, fogyasztóiknak nincs sok okuk versengésre egy gyakorlatilag korlátlanul rendelkezésre álló jószágért. Ha mégis sikerül érvényt szerezni a szellemi termékekkel kapcsolatos tulajdonjogoknak, ami a világhálón korántsem egyszerű, akkor szó lehet versenyről a vevők oldalán is. Mindazonáltal azt láthatjuk, hogy a világhálón megjelenő szellemi javak egy igen jelentős része ingyenes, és még az elvben fizetős digitalizált termékekhez is sokan fizetés nélkül jutnak hozzá. A fizikai javak árazásával szemben a korlátlanul és gyakorlatilag költségmentesen sokszorositható javak ingyenessége közgazdasági nézőpontból természetes, és a digitális formát öltött javak nem jelentéktelen részénél jellemző is. A vevők/fogyasztók versenye e javakért ezekben az esetben tehát nem értelmezhető, azonban e javak termelői annál inkább rivalizálnak a potenciális fogyasztók figyelméért.

A figyelem gazdasági jelentőségének a felértékelődése más oldalról, a termelö/ szolgáltató oldaláról is indokolható. Az eladók figyelme a "régi gazdaságban” is része volt a szolgáltatásoknak és az eladásoknak, sőt némely szolgáltatás esetében éppen a figyelem volt a központi alkotóelem. A közvetlenül emberekre irányuló, személyes szolgáltatások (tanítás, jogi és egészségügyi szolgáltatások például) mindig is nagy figyelmet igényeltek a szolgáltatótól. Ha mármost a termék maga is sok esetben „személyes szolgáltatásként” jelentkezik (és ez a helyzet sok, a hálón forgalmazott szellemi termék esetében a keresési szolgáltatásoktól a személyre szabott oktatásig), akkor a figyelem meghatározó tényezővé lép elö a termék értéknövelésében. Az információs javak és az információkkal telített fizikai javak esetében eladói oldalról a figyelem hármas szerepet játszik.

- Először is figyelemre van szükség a partnerek (igénybevevők, vásárlók, felhasználók) individuális igényeinek a letapogatásához. Nyilvánvaló, hogy az igények egyénenkénti azonosításához összességében több figyelemre van szükség, mint a nagyméretü piaci szegmensek feltérképezéséhez.

- Másodszor, nélkülözhetetlen a figyelem az ismert vevői igények kielégítéséhez szükséges speciális megoldások megkereséséhez.

- Harmadszor, mindinkább szükség van, a konkrét tranzakciótól függetlenül is, egyfajta általános figyelemre a tranzakcióban részt vevő felek között a partner személye iránt. Nemcsak az adott tranzakciót kell lebonyolítani tehát, hanem a kapcsolatot is gondozni kell a partnerrel kialakított viszony megőrzése, fejlesztése érdekében. 
Ez utóbbi fontosságát kutatások, felmérések sora támasztja alá vagy jó két évtizede. Egyesek odáig is elmennek a korábbi vevők elvesztésének okait keresve, hogy a vállalkozások a vevők mintegy 80 százalékát azért veszítették el, mert a szóban forgó vásárlók úgy érezték, hogy nem fordítanak rájuk elég figyelmet, vagy nem orvosolják panaszaikat (1. táblázat). Az ilyen veszteségek több mint kétharmadát tették ki azok, akik pusztán a figyelem hiánya miatt hagyták el végleg a szóban forgó kereskedelmi egységet.

\section{1. táblázat}

A vevők elvesztésének az okai

A vevő elvesztésének oka A vevők számaránya (százalék)

A vevő halála

Elköltözés az üzlet körzetéből

Barátoknál történő vásárlás

Másoknál kedvezőbb feltételekkel vásárol

Hiábavalónak bizonyult, rosszul kezelt vevői panaszok

Nem szentelnek nekik elég figyelmet a vásárlás során

Összesen

Forrás: www.onlinemarketer.de/know-how/hintergrund/attention-economy.htm.

A McKinsey \& Company legújabb kutatásaiból kiderült, hogy a megkérdezett ügyfelek csupán 13 százaléka mondta azt, hogy hüséges egyetlen márkához. A kutatás megállapította, hogy a megkérdezett ügyfelek 87 százaléka alkalom szerint vásárolt, 58 százalékuk pedig új márkára váltott (Lundin [2018]). ${ }^{3}$

A vevők iránti figyelem általános erősödése elsősorban az infokommunikációs technológiához társuló dematerializációból következik, de nem független a hiperkonnektivitástól sem, hiszen a szellemi termékek eladóinak a versenyét a globális dimenzió teszi igazán kiélezetté. A felborult egyensúlyi helyzet érdemlegesen javítja a vevők pozícióit, és kedvezően alakítja számukra a vevő-eladó viszonyt.

Az előbb kifejtettek ellenére egészen a legutóbbi időkig a közgazdaságtan nem foglalkozott érdemben a figyelemmel mint erőforrással. Az ezzel kapcsolatos problémákat a menedzsmenttudományokra hagyta, és jobbára az egyre csökkenő súlyú materiális erőforrásokra és fizikai javakra koncentrált.

\section{Figyelem a figyelemre - a közgazdasági kutatások új iránya}

A figyelem gyakorlati jelentőségének növekedését - ami már jóval a világháló megjelenése előtt megkezdődött - párhuzamosan lehetett érzékelni a médiaipar felvirágzásával és a marketing lendületes fejlődésével, tudományos problémaként való felbukkanása a közgazdasági kutatásokban azonban csak nagy késéssel következett be. ${ }^{4}$

\footnotetext{
${ }^{3}$ Lásd ezekről a kérdésekről részletesebben továbbá például Simon [1971], Franck [2019], Krieken [2019].

${ }^{4}$ A figyelem gazdaságtanának történeti gyökereiről részletesen lásd Festré-Garrouste [2015].
} 
A figyelem mint tudományos probléma iránt a 19. és 20. század fordulójáig főként a társadalomkutatók, a filozófusok és a művészetekkel foglalkozók tanúsítottak érdeklődést. A látványosságokkal, a színjátszással, a vetített képekkel összefüggő technológiai újítások nyomán a 19. század végén előtérbe került ez a probléma, de az igazán nagy áttörés a 20. század végén a média privatizálásával következett be. A médiaipar a figyelem klasszikus pszichológiai problémáját egyszeriben közgazdasági problémává alakította át (Thomas [2003] 90. o.).

A figyelem közgazdasági kutatásában a Nobel-díjas Herbert Simont tekinthetjük úttörőnek. ${ }^{5}$ Simon elsőként ismerte fel annak a szükségességét, hogy e tényezővel gazdaságelméleti keretek között foglalkozzanak. Ő világított rá arra, hogy az „információgazdag” világban egy újfajta hiánnyal kell szembesülnünk: „annak a bárminek is a hiányával, amit az információ elfogyaszt”. Simon szerint amit az információ „elfogyaszt”, az egyértelmü: „az [információt] befogadó figyelmét fogyasztja el. Így az információ gazdagsága a figyelemszegénységhez vezet.” (Simon [1971] 40-41. o.)

„Egy olyan világban, amelyben a figyelem az egyik legfontosabb szűkös erőforrás, az információ költséges luxuscikk is lehet, mert figyelmünket a fontosabb dolgokról a kevésbé fontosakra terelheti. Nem engedhetjük meg magunknak, hogy pusztán azért fordítsunk figyelmet valamilyen információra, mert véletlenül a szemünk elé került. Nem tudok arról, hogy sor került volna egy olyan információ- és kommunikációelmélet módszeres kidolgozására, amely az információk helyett a figyelmet tekinti szűkös erőforrásnak.” (Simon [1982] 81-82. o.)

Simon figyelemmel kapcsolatos korai kutatásai hosszú ideig nem találtak követőre. Az 1980-as évek elején írt sorai még ma sem vesztették el érvényességüket. Szemben a közgazdasági kutatásokkal, az üzleti gyakorlatban az utóbbi 20-30 évben egyre nőtt a „figyelemnek szentelt figyelem”, mégpedig két megközelítésben is: mind a termelö/eladó, mind a vevő figyelmét tekintve. A figyelem közgazdasági jelentőségének a felismerése azonban valójában csak az internet megjelenését követően következett be. A 20. század végéig ez a kutatási irány periferikus, illetve sporadikus maradt a közgazdasági elméletben. Az információtechnológiák rohamos fejlödése és a hozzá kapcsolódó jelenségek (elsősorban a világháló) azonban az 1990-es évtizedben drámaian megváltoztatták a tranzakciók környezetét és lefolyását, s az ügyletekben egyre nagyobb szerep jutott a figyelemnek. A figyelem mint gazdasági jelenség problémáját az 1990-es évek végén Michael Goldhaber állította középpontba egy előadásában (Goldhaber [1997b]).

Az új tranzakciós tér, a világháló látványos újításaira reflektálva Mandel-Van der Leun [1996] azt az előrejelzést fogalmazza meg, hogy az új gazdaság valutája nem a pénz lesz, hanem a figyelem (idézi Goldhaber [1997a]). Goldhaber azonban ennél is továbbmegy, és azt a következtetést vonja le, hogy a vállalatoknak ezért a „szemekre” és nem a dollárokra kell koncentrálniuk. Mivel egy személy figyelme egy nap csak 24 óra lehet,

\footnotetext{
${ }^{5}$ Simon már az 1940-es évek végétől foglalkozott olyan jellegű kutatásokkal, amelyeket ma a kognitív közgazdaságtan körébe sorolunk.
} 
ezért a figyelem igencsak korlátozott erőforrás. A figyelem megszerzése ezért nulla végösszegű játék. Ha egy vállalat elnyeri a fogyasztó figyelmét, akkor egy másik vállalat, legalábbis ugyanabban az időintervallumban, már nemigen számíthat rá. Ezért a „figyelemtranzakciók” - azok az esetek, amikor a vállalat és a fogyasztó interakcióban van egymással - Goldhaber [1997a] szerint meghatározó jelentőségűek.

Ha némiképpen túlzónak érezzük is azt a megállapítást, hogy a vállalatoknak a „szemekre” és nem a pénzre kell koncentrálniuk, annyi bizonyos, hogy manapság elsősorban a „szemek” hozzák a pénzt a termelöknek/eladóknak. A figyelem közgazdaságtanát a 2000-es évek végén - a már említett Michael Goldhaber korai müvei mellett $^{6}$ - Franck [1998] hozzájárulása fémjelezte. Goldhaber és Franck a probléma felvetésével maguk is a figyelem középpontjába kerültek.

\section{A figyelem természetrajza és meghatározása}

A tranzakciókra, illetve a tranzakciók tárgyaira fordított figyelmet a vevők részéről - minthogy nagyon szűkös erőforrásról van szó - úgy foghatjuk fel, mint szolgáltatást, amiért az eladóknak fizetniük kell. Megfordul az a hagyományos csereviszony, hogy az eladó elad, a vevő fizet. Az eladóknak is fizetniük kell. Az eladók természetesen már az információgazdaság kialakulását megelőzően is fizettek a vevők figyelméért. Az új ebben a tekintetben egyrészt a jelenség tömegességében, a fizetett összegek nagyságában, másrészt - mint az alábbi esetből is kiviláglik e fizetés módozataiban, a figyelemtranzakció lebonyolításában van. Az eladók azért fizetnek a vevőknek - illetve a potenciális vevőknek - és nem csak a reklámügynökségeknek vagy a médiának, hogy a vevők figyelme rájuk irányuljon. Az interneten különféle vállalkozások, illetve üzlettípusok jöttek létre, amelyek a figyelem felkeltésére és irányítására szerveződtek.

Mi is pontosan a figyelem? A figyelem az érzékeléshez, az emlékezethez stb. hasonló emberi tulajdonság, illetve pszichikai funkció. A magyar „figyelem” szó egyesíti magában az angol attention és az awareness fogalmakat. Az awareness (azaz éberség) a tudat állapotát fejezi ki. Ezzel szemben az attention célzott figyelmet jelent, azaz információk szelektív felvételeként, illetve feldolgozásaként értelmezhetjük. Míg tehát az éberség egyfajta kapacitás, a célzott figyelem e lehetőség kiaknázása, figyelmi kapacitásaink müködtetése.

„Napi gyakorlatunkban nemcsak az idővel és az erőfeszítésekkel igyekszünk takarékoskodni, hanem a figyelemmel, a törődéssel is. A figyelmet nem mindig könnyü a fizikai erőkifejtéstől és az időfelhasználástól elkülöníteni, mert azokkal szorosan összekapcsolódik. A figyelem azonban mindig szellemi erőfeszítést jelent, gondolkodást, tervezést, emlékek felidézését, értékelést, döntéshozatalt, felelősségvállalást. Különbözik az időtől, amiből korlátozott mennyiség áll rendelkezésünkre, de különbözik a fizikai erőfeszítéstől is [...] Hasonlít viszont rájuk abban, hogy az ember szellemi erőfeszítésekre [tehát a figyelemre - H. B.] való képessége is korlátozott." (Scitovsky [1990] 144. o.)

\footnotetext{
${ }^{6}$ Hickethier-Bleicher [2002] a probléma egy másfajta leírását és továbbgondolását adja.
} 
A figyelmet mind ez idáig egyetlen gazdaságelméleti kategóriába sem sorolták be egyértelmüen. Nem tekinthető egyértelmüen árunak, nem is szolgáltatás, szorosan véve nem is immateriális szellemi jószág, mégis nélkülözhetetlen (általában a gazdaság, de különösen) a mai gazdaság müködéséhez. Ugyanakkor - mint majd később bemutatjuk - bizonyos sajátos értelemben a figyelem jószág, cseretárgy (áru) és töke egyszerre. A figyelem fontos szerepet játszik a személyek önértékelésében, a kommunikációs folyamatokban, a nyilvánosságban és sok más, a 21. században erősen felértékelődő területen. ${ }^{7} A$ figyelem jelentősége különösen megnő versenyhelyzetben. Minthogy a globális információs gazdaságban féktelen verseny zajlik, ez is alátámasztja e tényező felértékelödését. A következőkben a figyelmet gazdasági megnyilvánulásaiban vesszük szemügyre: mint szűkös jószágot, mint cseretárgyat s mint tőkét.

Az információáradat újfajta szűkösséget teremt, és a figyelemért - mint gazdasági jószágért - vívott harchoz vezet. A példák kimeríthetetlenek, de elegendő itt talán csak a tévétársaságok öldöklő harcára utalni a nézettségért, ami nem más, mint a nézők figyelme. A szükösséget a figyelem esetében úgy értelmezhetjük, hogy a szellemi javak (információk) rendelkezésre állásához képest erősen korlátozott a felhasználásuk és befogadásuk képessége. Nem csupán a figyelem általában vett szűkösségével lehet dolgunk, a figyelemlekötés lehetősége bizonyos témákra, tartalmakra, tárgyakra, termékekre is korlátozott. Rákényszerülünk arra, hogy szelektáljunk a végtelennek tűnő információkínálatban, és takarékoskodjunk a figyelemmel.

\section{A figyelem mint szűkös jószág - az információs túlterhelés}

Az információs túlterhelés (information overload) egyáltalán nem új jelenség. Az ember információfeldolgozó képességének korlátait már a múltban is sokan feszegették. A 17. században élt ír katonaorvosról Barnaby Rich-szindrómának nevezték el a szüntelen panaszkodást az információk túlcsordulása, mértéktelen burjánzása miatt, amelyeket az emberek már nem győznek figyelemmel követni. Hogy képet alkothassunk a világhálón termelődő információtömeg nyomasztó mennyiségéről, tekintsük a következő számokat.

Az adatmennyiség gyarapodása igen elgondolkodtató. Naponta 2,5 kvintillió $\left(10^{30}\right)$ bájt adat jön létre. Ehhez adódik a tárgyak internete (Internet of Things, IoT) által generált adatmennyiség bővülése. Érdekesek egyébként ennek a hatalmas adattömegnek a belső arányai. A digitálisan tárolt információk 56,7 százaléka jelent meg filmekben, 31,5 százaléka kamerák és videofelvételek szülötte volt, 2,8 százaléka zene, 1,5 százaléka kommunikációhoz kapcsolódott, 7,5 százaléka pedig az egyéb kategóriába (idetartozik a világháló is) sorolható (Waters [2011] 7. o., idézi Bögel [2012] 66. o.). Ki kell emelni, hogy 2016-2017-ben - azaz két év alatt - keletkezett a világ összes adatforgalmának a 90 százaléka.

2018-ban az internetes kereséseknek több mint a fele már mobiltelefonról történik. A Google másodpercenként átlagosan több mint 40 ezer keresést dolgoz fel (napi

\footnotetext{
${ }^{7}$ Ezekkel a vetületekkel itt részletesebben nem foglalkozunk.
} 
3,5 milliárd keresést)! Ehhez adódik más keresőmotorok teljesítménye. Így világszerte összesen napi 5 milliárd keresést végeztek (Marr [2018]).

Az International Data Corporation (IDC) becslései szerint 2010-ben 1,2 zettabájt (1,2 ezer milliárd gigabájt $)^{8}$ új adat jött létre, szemben az előző évi 0,8 zettabájttal. Ez az adat az akkori becslések szerint 2020-ra 44-szeresére nő, és eléri a 35 zettabájtot (35 ezer milliárd gigabájt). Ám már 2018-ban 33 zettabájtnál jártunk, ami az IDC-t arra késztette, hogy 2025-re 175 zettabájt (175 billió gigabájt) új adat létrejöttét jelezze előre (Press [2020]). Evans-Hutley [2010] három fő okra vezette vissza ezt az adatrobbanást: a videózás általánossá válására a privát és az üzleti életben egyaránt, az internet mindent maga alá söprő fejlődésére és a mindenütt jelen lévő, szinte mindenkit érintő fotózásra (lévén hogy a telefon az egyre jobb kamerákkal lényegében mindenkinek a zsebében ott van). Ezt egészítette ki Marr [2018] a közösségi oldalakon (Facebook, Instagram, Twitter és a többi) megfigyelhető aktivitás gigantikus növekedésével. Mindehhez Press [2020] hozzáfüzte a mesterséges intelligencia és a robotika elképesztően gyors és a gazdasági és privát szféra szinte minden területére kiterjedő fejlődését.

Mindeközben világszerte nő a lakosság médiahasználata. Magyarországon a média által lekötött idő átlagosan meghaladja a négy órát a lakosság időmérlegében. Ez sincs arányban azonban a számtalan tévécsatorna által kínált parttalan információtartalommal. A túláradó információfolyam, a túlzás nélkül információrobbanásnak nevezhető fejlemények ellenére, amelyek áthatják a gazdasági élet egészét, az információ közgazdaságtana ma szinte egyáltalán nem foglalkozik az információs túlterheléssel. Sokkal inkább a hiányos információk kötik le a közgazdászok figyelmét (aszimmetrikus információk, bizonytalanság stb.). ${ }^{9}$ Bizonyos döntéseknél természetesen felmerül a hiányos információk problémája. Nem az ennek szentelt figyelem létjogosultságát vitatjuk, hanem az erőfeszítések eltúlzott mértékét a probléma súlyához mérten, különösen, ha azt a mindent elárasztó információtömeg kezelhetetlenné válásával - mint mára alapvetővé vált közgazdasági problémával - vetjük össze.

A 21. században a fejlett gazdaságokban (de a kevésbé fejlettekben is) nem az információ, ${ }^{10}$ hanem az észleléséhez, feldolgozásához, megemésztéséhez szükséges figyelem szükös. Ebből viszont következik, hogy e szükös jószágot, a figyelmet hatékonyan kell allokálni a különféle felhasználási lehetőségek között. Az allokációs problémát azonban csak akkor lehet jól megoldani, „ha megtaláltuk a szükös erőforrás mérésére szolgáló eszközöket” (Simon [1982] 151. o.). A bitek nem nyújtanak megfelelö mérőeszközt a figyelem számbavételére. A kérdéssel mélyebben foglalkozó kutatók általában megegyeznek abban, hogy a figyelem legjobb (bár korántsem tökéletes) mércéje az idő. A University of San Diego egy tanulmánya (Dybwab [2009]) szerint az átlag amerikai már 2009-ben napi 11,8 (!) órát töltött információfogyasztással, ezalatt napi 34 gigabájt információt fogyasztott. Az információk forrásait, illetve e források arányát mutatja a 3. ábra.

\footnotetext{
${ }^{8}$ A zettabájt (ZB) a számítógépes adattárolás egysége, 1 zettabájt egyenlő sextillion $\left(10^{21}\right)$ bájttal.

${ }^{9}$ A bizonytalanság sok szálon függ össze az információval. Úgy is fogalmazhatunk, hogy a bizonytalanság oka az információ hiánya, az információ pedig a bizonytalanság megszüntetése.

${ }^{10}$ Ez a megállapítás akkor is igaz, ha az információkat némely esetben mesterségesen szűkössé teszik, elzárják vagy adagolják.
} 
3. ábra

Az amerikaiak információfogyasztásának arányai információforrások szerint (százalék)

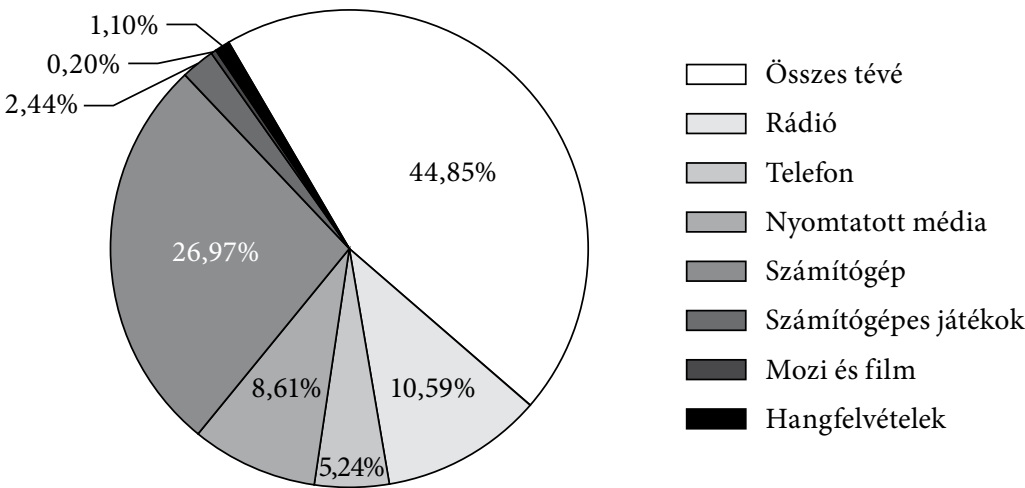

Forrás: Dybwab [2009].

A figyelem mérésére felvillanyozó (és technikailag is jól kezelhető) lehetőséget kínálnak az internetes oldalak. Ezek automatikusan mérik az egy-egy oldalra felcsatlakozók ott eltöltött idejét.

„Pszichológiai tanulmányok kimutatták, hogy erős korreláció van aközött, hogy a felhasználók mit sorolnak az érdekes tételek kategóriájába, és hogy mennyi ideig nézik azt a tételt. (Gondoljunk csak arra, hogyan olvasunk újságot.) [...] A JAVA alkalmazásával [...] a felhasználó magatartásának azt az elemét mérhetjük [...], amelyiket akarjuk, beleértve az egyes tételeknél eltöltött időt." (Shapiro-Varian [1999] 36-37. o.)

Míg az, hogy egy-egy adott termék (virtuális vagy valóságos, szellemi vagy fizikai) felkeltette-e valakinek a figyelmét, és ha igen, mennyire, viszonylag könnyen mérhetö, sokkal nehezebb megmérni a figyelemkapacitást (awareness) akár az egyén, akár pedig a csoport esetében. Ellenben az egészen nyilvánvaló, hogy - legalábbis a fejlett országokban - ma mindenkinek lényegesen nagyobb információtömeghez és szellemi gazdagsághoz van szabad hozzáférése, ${ }^{11}$ mint amekkorát befogadni és feldolgozni képes.

\section{A big data-probléma}

A figyelem azonban nem csupán a fogyasztó számára hasznos, és nem csupán a kívánt információk befogadására irányul. Újabban externáliaként, tehát az információtermelö folyamatok mellékhatásaként tárgyalják az információszennyezést, amelynek számtalan formája ismert: a kéretlen reklámanyagoktól a spameken keresztül a gépeket megtámadó férgekig és vírusokig. A felesleges információk eltömítik az

\footnotetext{
${ }^{11}$ Természetesen azoknak, akiknek van internetcsatlakozása. Ma ez már körülbelül négymilliárd ember, a Föld lakosainak több mint fele (a teljes populáció 2020. december 12-én 7,8 milliárd fö http://nepesseg.population.city/world/).
} 
információs csatornákat, megnehezítik a keresést, ezáltal kárt okoznak mind az információtulajdonosoknak, mind az információfogyasztóknak, azaz negatív externális hatást fejtenek ki. A szakirodalomban három megoldási javaslattal találkozhatunk e speciális „szennyeződés” okozta jóléti veszteségek kiküszöbölésére: a technológiaival (spamszürők), a jogi-intézményi és a piaci alapúval (Krautés szerzőtársai [2005]). Az utóbbi az externáliák coase-i kezelésére vezethető vissza. Az ezzel foglalkozó szakirodalom abból indul ki, hogy ha fizetni kellene az elektronikus levelekért, az fegyelmező hatást gyakorolna a levelek feladóira, a címzettek számára pedig egyfajta jelezésként működne a tartalom komolyságát illetően, mielőtt még elolvasnák a leveleket. Festré-Garrouste [2015] ugyanakkor felhívja a figyelmet arra, hogy a spamek kiszürésére alkalmas különböző piaci mechanizmusok bonyolultabbak, mint egy jól müködő ingyenes spamszürö.

Az információs túlterheléssel összefüggésben felmerült az úgynevezett big dataprobléma. McKinsey a big datára olyan adategyüttesként hivatkozik, „, amelynek a mérete túlnyúlik a tipikus adatbázis-kezelő szoftverek rögzítési, raktározási, kezelési és elemzési képességén" (Manyika és szerzőtársai [2011] 1. o.). Edd Wilder-James (korábbi nevén Edd Dumbill), az O’Reilly Media, Inc. munkatársa pedig olyan adattömegként definiálja, amely „meghaladja a hagyományos adatbázis-rendszerek adatfeldolgozó kapacitását. Az adattömeg túl nagy, túl gyorsan mozog, vagy nem illeszkedik az adatbázis architektúrájához." (Wilder-James [2012], kiemelés tőlem - H. B.) ${ }^{12}$ A big datával kapcsolatos problémák jelentkezhetnek az adatok rögzítésében, megörzésében, raktározásában, keresésében, továbbításában és elemzésében, amely utóbbi talán a legnagyobb kihívás.

„A big data-jelenségen nem csak az adatok mennyiségének növekedése, a mennyiségi értelemben vett adatrobbanás értendő. Az infokommunikációs piac elemzésével foglalkozó, kiemelkedő szakmai tekintélynek örvendő Gartner Group a nagy adatbázisok három fontos tulajdonságát emeli ki. Az első ezek közül az adatok mennyisége (volume) [...], a második az adatok változatossága (variety), az adatfajták és -források sokfélesége [...], a harmadik tulajdonság a sebesség (velocity), ami egyrészt az adatok keletkezésének a gyorsaságára vonatkozik, másrészt a hasznosításukhoz rendelkezésre álló időre.” (Bőgel [2012] 67. o.)

Az információs túlterhelés problémáját még az sem enyhíti érdemlegesen, ha a „kutyaharapást szőrével” elv alapján éppen a számítógép tágítja ki egészen valószínütlen mértékben az információfeldolgozó kapacitásunkat. ${ }^{13}$ Ennek az eszköznek az igénybevétele azonban szintén figyelmet és kompetenciát, az utóbbiból következően tanulást igényel. A legnagyobb kihívás az értékes információk kiszürése a parttalannak tünő információözönből. Az adatok mennyiségi növekedése nem feltétlenül jelenti a használható információk és különösen nem a tudás növekedését. A nem

${ }^{12}$ A big data-jelenséggel Bögel [2012] részletesen foglalkozik.

${ }^{13}$ Vannak olyan számítógépes programok, amelyek gyakorlatilag figyelemhelyettesítők. Ilyen a Yahoo spamszűrője. Hasonló figyelemhelyettesítők például az ár-összehasonlító oldalak (Pricerunner: https://www.pricerunner.co.uk/ és a PriceGrabbert http://www.pricegrabber.com/). Ezt a célt szolgálják a liciteket az árverés utolsó pillanatában elhelyező, úgynevezett orvlövészprogramok is (Négyesi [2004]). 
kívánt reklámok példaként szolgálnak azokra a tartalmakra, amelyeknek nincs igazi információértékük, mert a címzett számára nem relevánsak. Az információáradat kettős szelekciós problémát okoz. Először is a rendelkezésre álló adatokból és szellemi javak közül ki kell választani azokat, amelyeknek információértékük van számunkra, másodszor további szelekciós és értékelési problémák keletkeznek a kiválasztott adatok feldolgozásakor, értelmezésekor (Falkinger [2008]). Az első alapvető kérdés ezekkel kapcsolatban az ember információfeldolgozó kapacitása.

„A központi idegrendszer egyszerre csak néhány dologgal képes foglalkozni. [...] Fenn kell állnia annak a lehetőségnek, hogy előbb arról dönthessünk: mire irányítsuk a figyelmünket, és csak azután arról, hogy mit is kezdjünk a figyelembe vett dolgokkal." (Simon [1982] 201-202. o.) Coursey-Mason [1987] kísérletei során azt találta, hogy az emberek csak kevés (5-10) választási lehetőséget tudnak áttekinteni (idézi Denzau-North [1994] 9. o.). Rákényszerülnek arra, hogy szelektáljanak az óriási információkínálatból, és takarékoskodjanak a figyelemmel. Kiválasztani azonban a figyelemre érdemes dolgok közül a legkedvezőbbet csak akkor tudják, ha visszajelzéseket kapnak. A figyelemnek ez a határa azonban különböző technikákkal bővíthető.

Vannak esetek, amikor az információhoz való hozzájutás nem esik egybe a feldolgozással. Ha például egy vállalat megszerez egy listát a potenciális vevőkről, nem biztos, hogy azonnal hasznosítani tudja. Lehet, hogy a lista statisztikai feldolgozást, elemzést igényel ahhoz, hogy használható marketingstratégiához segítse a céget. A kapacitásaink alapján feldolgozható információknak általában a sokszorosát birtokoljuk. Több helyütt is megjelentek olyan adatok, amelyek szerint a vállalatok a rendelkezésükre álló adatbázisokat mindössze 10-15 százalékban használják ki. Attól a ponttól kezdve beszélhetünk a vállalatok túlterheléséröl, amikor az információk mennyiségi növekedése már nem javítja a döntések minőségét, sőt a kezelhetetlen információtömeg - túljutva az optimumon - rontja a döntések minőségét (4. ábra).

\section{4. ábra}

Az információs túlterhelés

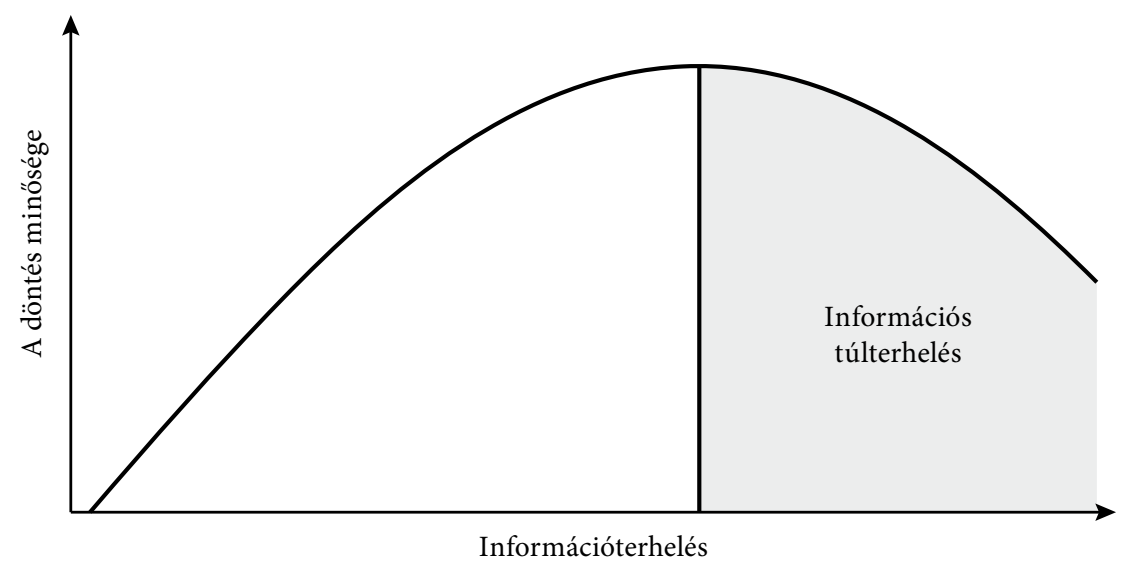

Forrás: Rajabzadeh és szerzőtársai [2011] 354. o. 


\section{Alkalmazkodás az információbőséghez, avagy a figyelmi kapacitások tágulása}

A figyelem aktuális szűkösségének értékeléséhez látnunk kell az ellentétes irányú, hosszú távú trendeket is. Vegyük számba azokat a tényezőket, amelyek a figyelmi kapacitás tágulása irányában hatnak!

Nemcsak a villanyvilágítás feltalálása és elterjedése, hanem a napi munkaidő csökkenése is hozzájárult a szabad figyelem nagymértékű kiszélesedéséhez. Ez a folyamat összhangban áll a technikai újdonságok (telegráf, rádió, tévé, internet stb.) feltalálásával, az észlelési és kommunikációs lehetőségek robbanásszerü gyarapodásával. Ezáltal fokozódik a szelektálás a közlés és a kommunikációs folyamatok között. A modern társadalomban a média teremtette meg más társadalmi alrendszerek számára a „figyelemirányítást”, de - e pozitív externális hatása mellett - elvonta a figyelmet más társadalmi alrendszerektől, azaz maga is erősíti a figyelem szűkösségét. Minél több médiatermék van a médiapiacon, annál nehezebb bárkinek is a saját céljaira elegendő figyelmet lekötnie. A reklámok figyelemlekötő hatása is egyre gyorsabban kopik. E probléma megoldási kísérletei azonban tovább növelték a problémákat (Thomas [2003]).

A figyelmi kapacitások tágulásához nagymértékben járul hozzá az oktatás kiterjesztése és színvonalának a növekedése. A kiművelt emberfők nyilvánvalóan nagyobb információbefogadó és -feldolgozó kapacitással rendelkeznek, mint az alacsonyabban képzettek. Mindazonáltal - ezen ellenható tényezők ellenére - folyamatosan nő az információs túlterhelés. Az információs túlterhelés nemcsak a vállalatok, hanem az egyének számára is számos negatív következménnyel jár, a stressztől kezdve a más tevékenységek (sport, személyes és családi kapcsolatok stb.) háttérbe szorításáig. Mindazonáltal mind ez ideig nem születtek igazán hatékony megoldások a túlterhelés csökkentésére a megállíthatatlanul szaporodó információk világában.

\section{A figyelem mint cseretárgy és tőke}

A figyelmet ugyanúgy lehet adni-venni, mint a tranzakciók hagyományos tárgyait, és ez már az ipari rendszerben is így volt. A médiában reklámidőt vásároló vállalatok, a pszichiáter díványán személyes figyelmet „beszerző” páciensek, az egyedülálló idősek, akik „társalkodónőt” vagy gondozót keresnek, tulajdonképpen a figyelem iránt támasztanak igényt.

\section{A figyelem adásvétele}

A figyelem vásárlására az infokommunikációs technológia hatására új lehetőségek nyíltak, s az effajta tranzakciók új dimenziókat nyertek. A figyelem vásárlásában persze kifejeződik a modern/posztmodern világ elidegenedettsége. A nigériai ibo törzs tagjainak aligha van szükségük társalkodónőre vagy pszichiáterre, de a múlt század eleji magyar falvakban is volt még olyan erős a közösség, hogy az ott élőknek 
a figyelmet nem kellett fizetett szolgáltatásként megvásárolniuk. A modern/posztmodern világban azonban a figyelem mint termelöi és fogyasztói szolgáltatás az értékteremtés jelentős forrása.

Az egykori www.cybergold.com című weboldal gazdái még a 2000-es évek elején rájöttek arra, hogy milyen szükös és ezért milyen értékes a vevők figyelme. A weboldal úgy működött, hogy ha valaki jelentkezett a Cybergoldnál, és az erre a weboldalra feltett reklámját egy érdeklődő megnézte, akkor az érdeklődő egy kis pénzt tudott keresni, amit a Cybergold egyenesen átutalt a számlájára. Az innovatív üzlet feltalálója, Nat Goldhaber úgy fogta ezt fel, mint egy negatív árakkal megjelölt reklámot. Goldhaber ezt az egészet a „figyelem alkuszdíjának" nevezi, amelyen a figyelem vásárlásakor, illetve eladásakor szereplö összeget érti. E vállalkozási forma azonban kivételes maradt. Más „fizetséget” mindazonáltal nagyon sok cég ajánl fel a figyelemért (a fogyasztó számára értékes vagy érdekes információkat, nyereményeket stb.). A fogyasztók ekkor csak olyan reklámokat és termékismertetőket kapnak, amelyek az érdeklődési körükbe tartoznak, és amelyeknek figyelmet akarnak szentelni. Ma már nem úgy tekintenek a cégek a vásárlói figyelemre, mint ami ingyenes és spontán, hanem mint árura vagy szolgáltatásra, amit be kell szerezniük (Fichter [2001]).

Később már a Cybergold sem pénzt kínált a hirdetések megtekintésért, hanem ingyenesen letölthető zenét, videót stb. E jutalmak, illetve pénzösszegek egyfajta információs szürőként müködnek, hasonlóan ahhoz, mint amikor a fogyasztók megbízottja a fogyasztók utasításainak megfelelően megszüri az információkat. A figyelemért nyújtott ellenszolgáltatások is aláhúzzák a vásárlói figyelem megváltozott kezelését és nagyraértékelését. A hallgatók/nézők öntudatlanul is érzik, hogy a hirdetések tulajdonképpen egy szűkösen rendelkezésre álló jószágot kérnek tőlük, s ezért joggal tartanak igényt kompenzációra. Számukra a reklám legtöbbször puszta időrablás. Elvárják, hogy - a reklámok akár passzív végignézéséért cserébe - az eladók legalább áttételesen fizessenek nekik, vagy szórakoztassák őket. A jelenség már nem is teljesen új keletü. Egy szakértő már vagy másfél évtizeddel ezelőtt úgy fogalmazott:

„A reklámozás rendkívül bonyolulttá vált. Rájöttünk, hogy meg kell ajándékoznunk az embereket. A fogyasztókat olyan tartalmakkal lehet jobban lekötni, amelyekről nem ordít messziről, hogy hirdetések: a Forrester Research becslése szerint az elkövetkező évben 7 milliárd dollárral csökkennek a televíziós hirdetési bevételek. A kieső bevételekből 2007-re 4,6 milliárd vándorol át olyan "figyelemvásárló« megoldásokhoz, mint a személyi videofelvevő készülékek (Personal Video Recorder, PVR) és a lekérhetö videoszolgáltatás (video-on-demand, $V O D$ ), előfizetők számára készített szponzorált filmek és sztárinterjúk." (Dennott [2004])

A nézők nem azért ülnek le a tévékészülék elé, hogy a reklámokat nézzék, hanem azért, hogy az kielégítse érdeklődésüket a politika, a divat vagy bármilyen számukra fontos dolog iránt, illetve, hogy a „doboz” krimikkel, szappanoperákkal, koncertekkel vagy más müsorokkal szórakoztassa őket.

„Az általános megközelítéssel (a reklámozók a műsorszerkesztésért fizetnek a tévének) ellentétben valójában a reklámozók közvetve a vevőknek fizetnek: a müsor-összeállitás 
kompenzálja a vevőket a hirdetésért. Azokat a hirdetéseket, amelyek csökkentik a hasznosságot, nem célszerü újságokba, nyomtatott médiába tenni, mivel az olvasók sokkal könnyebben figyelmen kívül hagyják őket, mint ha a tévében látnák vagy esetleg a rádióban hallanák. A feltételezés szerint tehát a nyomtatott sajtóban nagyobb a hasznosságnövelő hirdetések hányada, mint a tévében vagy a rádióban.” ${ }^{14}$ (Becker-Murphy [1993] 961-962. o.; kiemelés tőlem - H. B.)

Az egyének leginkább a saját személyükkel kapcsolatos információknak szentelnek figyelmet, s ugyanez áll a vállalatokra. Vagyis a cégeknek, ha figyelmet akarnak magukra irányítani, nem magukra, hanem klienseik személyére kell koncentrálniuk.

Hatvan amerikai vezetővel készítettek vizsgálatot. Egy hétig folyamatosan figyelniük kellett a híreket, majd értékelniük kellett őket aszerint, hogy melyik keltette fel az érdeklődésüket. A kutatás fontos eredménye volt, hogy az érdeklődés nagymértékben függött a hír személyes jellegétől. Vagyis a vezetők arra figyeltek, amit valahogy kapcsolatba lehetett hozni a személyükkel (Fichter [2001] 8. o.).

Funkcionális és piaci összefüggésben a figyelem tulajdonképpen sajátos munkatermék (munkateljesítmény, szolgáltatás), és mint cserejószágot természetesen pénz fejében cserélik. Franck [1998] szerint a csererendszer elég pontos információkat ad a társadalomban a figyelem elosztásáról, amelynek arányai a szermélyes és társadalmi elismerést tükrözik. A figyelem „tőzsdéje” a társadalmi nyilvánosság, az internet pedig a figyelem globális piacaként fogható fel.

A figyelmet mint cserejószágot bizonyos szempontból értékmérőként is kezelhetjük, és ezzel hozzárendelhetünk egy pénzfunkciót, tudniillik az általános csereeszköz funkcióját, ami megkülönbözteti a közönséges jószágoktól. A pénzzel ellentétben azonban a figyelemnek csak korlátozott értékmegőrző funkciója van. Azok számára, akik elsődlegesen felhalmozták, részlegesen értékmegőrző (nem minden körülmények között természetesen), azonban a figyelmi tökét csaknem lehetetlen transzferálni mások számára. A figyelem ugyanis - eltérően a pénztől és az áruktól - nem alkalmas a továbbcserélésre. A figyelem mint csereeszköz ritkán kerül helyettesítő funkcióba is (pénz vagy áruk pótlása).

\section{A figyelmi töke}

A figyelem nem csupán cseretárgy, hanem tőkeként is kezelhető (Lanham [2006]). Dicsőség, kiválóság és presztízs mind a felhalmozott figyelem ${ }^{15}$ megnyilvánulási formái. Ebben az értelemben a figyelemnek értékmegőrző funkciója van, bár ezt nem lehet minden további nélkül összehasonlítani a pénz hasonló funkciójával. Az ismertségi fok

\footnotetext{
${ }^{14}$ A hirdetések nem csak időt rabolnak, vannak hasznos, informatív fajtáik is. Ezeket nevezi a szerzőpáros hasznosságnövelö hirdetéseknek.

${ }^{15}$ Ennek kiaknázhatóságát jelzi, hogy Attention Trust néven már egy cég is alakult, amely „számontartja" a nála jelentkező kliensek figyelemkészletét, és arról - természetesen nem ingyen - rekordokat készít, amelyet a megrendelők megjeleníthetnek a számítógépükön.
} 
és tekintély tőkévé változik, ami jövedelmet hoz, és fontos része az értékteremtési folyamatnak. Fontos hangsúlyozni a figyelmi tőke felhalmozásában az internet (azon belül a közösségi hálók) különleges szerepét. Enélkül aligha lehetne sztár a dél-koreai rappelö szinte napok alatt, és nem tarthatna igényt milliók és százmilliók figyelmére. Hasonlóképpen nehéz lett volna elképzelni a világháló hiányában Obama sikerét első megválasztásakor - rekordsebességgel összegyüjtött figyelmi tőkéjének köszönhetően. Mindehhez azonban nyilvánvalóan szükség van arra, hogy a „figyelemtőkés” jól „adja el magát”, éljen (esetleg visszaéljen) azzal, hogy valamilyen okból a figyelem középpontjába került. A kiváló vagy híres sportolóknak, zenészeknek vagy színészeknek az ismertségük kifizetődik - például szponzori szerződések, reklámfellépések formájában.

A figyelmi tőke tulajdonosai korántsem csak passzív élvezői a rájuk összpontosuló érdeklődésnek, hanem - akárcsak a valódi tőkével - gazdálkodniuk is kell a figyelemmel. A média és a politika sztárjainak a köréből sok példát lehetne hozni a figyelemmel való tudatos gazdálkodásra. A gazdasági folyamatokban nemcsak a személyre szabott figyelemtökének van fontos szerepe, hanem annak is, ami a vállalatokra vagy termékekre vonatkozik. Így egy vállalat imázsa vagy egy védjegy ismertsége függ a felhalmozott figyelemtöl.

A legszemléletesebb példája ennek az információs technológiában utazó cégek egészen elképesztő méretü tőzsdei túlértékelése a 2001-es összeomlás előtt. Amit e cégek részvényesei árfolyamnyereségként, menedzseri jövedelemként elkönyvelhettek, annak nagy része annak volt köszönhetö, hogy képesek voltak magukra vonni a figyelmet. A publikum beléjük vetett bizalma, ismertségük, jó sajtójuk „figyelmi tőkeként” működött, amely jövedelmet fialt számukra. És ha ezt a felpumpálási folyamatot keserves kijózanodás követte is, maga a jelenség mindenképpen paradigmaváltás előszele a gazdaságban (Fichter [2001]).

A figyelmet nagyrészt az újfajta média osztja el, de ez az elosztás meglehetősen egyenlötlen.

„A modern tömegkommunikáció centripetális figyelmi struktúrát generált, amely a hírnevet és a hírességeket palackozza eladásra. Az ehhez hasonló centripetális figyelemstruktúra, amely olyannyira spontán módon következik az emberi természetből, hogy ősi öröklött magatartásmintának kell lennie, része a figyelmi tőkének. És így jutunk elöre a hercegnőkhöz, mozisztárokhoz és kosárlabda-játékosokhoz. Ez a struktúra hatékonyan összpontosítja a figyelmünket, de csak nagyon kevés emberre. A figyelmet kevés kézben koncentrálva, a celebritások világa ugyanazt a szerencsétlenséget és a gazdagság szélsőséges elosztását hozza magával, amelyet oly jól ismerünk a fizikai javak uralta gazdaságból." (Lanham [2006] 11. o.; kiemelés tőlem - H. B.)

Csak kevesen jutnak nagy mennyiségü figyelemhez, a többieknek morzsákkal kell beérniük. Ez az elosztási konfliktus és egyenlötlenség tovább élezi a figyelemért folytatott - sokszor a nyersanyagokért vagy az anyagi erőforrásokért folyó versenynél jóval kíméletlenebb - konkurenciaharcot. A figyelem nem növekszik lineárisan a megfigyelések vagy a megfigyelők számával. Extrém esetben a figyelem felhalmozása negatív eredményt is hozhat tulajdonosának. A hírnév és a nagyrabecsülés diszfunkcionális is lehet, amikor inkább árt, mint használ annak, aki felhalmozta. 


\section{Viselkedési tényezők a figyelem allokációjában}

Egy másik (viselkedési közgazdaságtani) megközelítés szerint az információk befogadása és az irántuk megnyilvánuló figyelem nem eleve adott, az információfelvétel és a feldolgozás nagymértékben függ az információk „tálalásától”.

\section{Keretezési hatás és elérhetöségi elöitélet az információk értelmezésében}

A piaci információk iránt feltámadt figyelem (vagy éppen annak hiánya) erősen függ attól is, hogy az értesülések milyen keretben (környezetben) kerülnek elénk. Egyfajta kahnemani csomagolási vagy keretezési hatás (framing effect) érvényesül nemcsak a döntésekben (lásd Tversky-Kahneman [1981]), hanem az információk manipulálásában, közvetítésében, megértésében és feldolgozásában is (amely kognitív művelet természetesen erősen hat az információk alapján meghozott döntésekre). Valószínü, hogy a negatív formában megfogalmazott információkra jobban figyelnek, $s$ az új és szokatlan információk is inkább számíthatnak figyelemre, mint a megszokott keretbe illeszkedők. A szenzációk és katasztrófahírek növekedése világszerte tapasztalható jelenség. Ezt messzemenően kihasználják az üzleti életben is a termékek/szolgáltatások iránti figyelemfelkeltésre.

Tversky-Kahneman [1981] nyomán a kutatók a keretezési hatás több oldalát tárták fel. Keretezési hatást váltanak ki az információk mennyiségében mutatkozó különbségek (vagyis az, hogy a rendelkezésre álló információkból mennyit közölnek) éppúgy, mint a probléma elöadásának módja vagy a lehetséges olvasatok száma, azaz az előadás egy- vagy többértelműsége. Ezek a körülmények a vevők számára különbségeket okozhatnak az egyébként tökéletesen azonos információk értékelésében, feldolgozásában, döntéssé konvertálásában. Csak példaként érdemes érzékeltetni a hatás különbségeit pozitív vagy negatív keretezés esetében (például a téli vásár/leértékelés vége versus áremelés; adókedvezmény gyerekek után versus gyermektelenségi adó; egyensúlyjavító intézkedések versus megszorítások).

Az emberek figyelme, amelyet egy adott cégnek szentelnek, egészen másként alakul, ha a szóban forgó vállalkozást internetes cégként mutatják be nekik, mint akkor, ha olyan kezdő vállalkozásként, amelynek egyelőre még telephelye sincs. A téli vásár utáni eladásokat bizonyára nagyban befolyásolná, ha a leértékelésről harsogó árcédulák után olyanokat raknának ki, amelyeken a kiárusítás alacsony árai pirossal át lennének húzva, és föléjük az lenne írva, hogy új, magasabb ár. Ilyen malőrt azonban még a legtehetségtelenebb kereskedő sem követ el.

Hasonlóképpen befolyásolja a szellemi javak és információk befogadását, megértését, a rájuk fordított figyelmet az úgynevezett elérhetöségi elöítélet (availability bias). Azt, hogy egy adott információt milyen fontosságúnak ítélünk, mennyire figyelünk rá, attól tesszük függővé, hogy milyen könnyen hívjuk elő a memóriánkból. Nyilvánvaló, hogy a rendszeresen ismétlődő, nagy gyakoriságú információkat könnyebben tudjuk felidézni, mint az olyanokat, amelyekhez ritkán jutunk. Az ember mentális mechanizmusai azonban megfordíthatják ezt az összefüggést is: nagyobb súlyt 
tulajdonítanak azoknak az információknak, amelyek valamilyen okból nagyobb hatást tettek rá, s ezért könnyen előhívhatja őket az emlékezetéből, annak ellenére, hogy ritkán fordulnak elő. Azt hihetnénk, hogy a befektetők sokkal tudatosabb és racionálisabb vásárlók, mint a reklámok által elcsábított magánszemélyek, de ez nincs így. A befektetői döntéseket sem csupán a racionális megfontolások vezérlik, hanem nagyban hat rájuk az elérhetőségi elöitélet (Ariely [2014]). Ez az elöítélet lényegében a következőkben ragadható meg a döntések során:

- gondolkodásunkat gyakran erősen befolyásolja az, ami személyesen fontos, jelen idejü és drámai;

- a félelem jobban motiválhatja pillanatnyilag a beruházási döntéseket, mint a valóság;

- amint a hozamkörnyezet eltolódik, sok befektető azzal a választással szembesül, hogy vagy a céljait, vagy a hozzáállását változtatja meg (Franklin Templeton Investments [2012a], [2012b]).

A Franklin Templeton Investments [2013] felmérése még azt is igazolta, hogy egy drámai válság tapasztalatai nemcsak pillanatnyilag, hanem hosszabb időre is befolyásolhatják a gazdasági helyzet, illetve lehetőségek megítélését. 2012-ben a felmérésben részt vevőknek meg kellett becsülniük az S\&P500 hozamát (amely 2008-ban jelentősen, 37 százalékkal esett). A 2009 és 2011 közötti három évben a valóságos hozamok, ha változó mértékben is, de rendre emelkedtek $(26,5,15,1,2,1$ százalékkal). 2012-ben viszont a válaszadók rendre 66, 49, 70 százaléka úgy vélte, hogy a hozamok estek vagy nem változtak az említett években. A befektetők gondolkodását láthatóan jobban befolyásolta az emlékezetükböl könnyen előhívható korábbi drámai történés, mint a valóság.

Az emberek egymás iránti figyelmét saját információik tesztelésének és mások információi hasznosításának a szándéka is motiválja. A gazdasági szereplők nem pusztán kíváncsiságból vagy mások iránti együttérzésből törődnek azzal, hogy mások mit mondanak vagy tesznek. Nem önzetlenül figyelik árgus szemmel a többiek gazdasági ügyleteit. Korántsem csak a figyelemcsere és az ennek révén megvalósuló társadalmi kapcsolatépítés motiválja őket, hanem partnereik várható lépéseinek, üzleti megoldásainak, reakcióinak a kipuhatolása is. Mások magatartásának a megfigyelése különösen nagy lendületet vett az internet révén, ahol a cégek viszonylag egyszerü eszközökkel, például a vásárlók „kattintásfolyamát”, kereséseit követve tájékozódhatnak a vevők szándékairól, magatartási jellemzőiről. Az így szerzett adatokat felhasználva természetesen manipulálni is lehet a fogyasztókat. Jóindulatú megközelítéssel azonban azt mondhatjuk, hogy a vásárlók webes aktivitásának nyomon követése nélkülözhetetlen a cégek számára a vásárlói igények individualizált kielégítéséhez.

A figyelem ökonómiájáról szóló viták mögött még nem állnak eléggé megnyugtatóan megalapozott tanulmányok. Az első empirikus adatokat a figyelem irányításáról Davenport-Beck [2002] globális vizsgálatok alapján publikálta. A tárgykörben ez idáig kevés empirikus eredmény született, ez a tudományosan érdekes és eredményekkel kecsegtető kutatási irány tehát még éppen csak elindult. 
A figyelem szociális dimenziója - a vevők figyelmének megragadása új médiumok révén

Az elméleti megfontolások után most a figyelemmel kapcsolatos gyakorlati problémákat vizsgáljuk az új tranzakciós térben. A következőkben kifejtettek példaként is szolgálhatnak azoknak az általánosabb összefüggéseknek a specifikálásához, amelyeket az elözőkben tárgyaltunk. Egyetlen tevékenységet emelünk ki: a reklámot, noha tökéletesen tisztában vagyunk azzal, hogy a piac meghódítása négy elem szinergikus alkalmazását jelenti a vállalati gyakorlatban: a termék, az ár, az elosztási csatorna és a marketingkommunikáció alakítását, amely utóbbinak része a reklám. Nemcsak terjedelmi korlátok kényszerítenek a reklám kiragadására az említett négyes rendszerböl, hanem az is, hogy a figyelemmel kapcsolatos problémák talán a reklámmal hozhatók a legszorosabb kapcsolatba.

A figyelem a szociális folyamatokban, valamint az emberek közötti kommunikációban is szerepet játszik. A szociális folyamatokat Fichter [2001] szerint az egymásnak szentelt figyelem folyamatos cseréjeként is leírhatjuk. Az emberek közötti kapcsolatok elementáris formája, hogy figyelnek arra, amit a másik mond, ami vele történik, amit a környezete állít róla. A figyelem cseréje három részproblémára különíthető el:

- azoktól az emberektől kell a lehető legtöbb figyelmet „fogadni”, akiket a legtöbbre tartunk;

- a saját figyelmünk értékét maximalizálni kell azok szemében, akiktöl a legnagyobb mértékben függünk;

- a „figyelemcsere-ügyletet” le kell bonyolítani.

A figyelem allokációjának fenti lépései feltételezik mind a partnerek azonosítását, elhelyezésüket egy képzeletbeli ranglétrán, mind pedig saját magunk pozicionálását a figyelemért folytatott versenyben. Ez utóbbi szintén csak identitásunk kimunkálásán és külsődleges kifejezésén keresztül érhető el. A figyelmet mint elosztandó erőforrást az emberi kommunikációs folyamatokban a gazdasági szereplők közötti aktivitás növelésének intra- és interszubjektív formájaként kezelhetjük. Itt a személyes nagyrabecsülés, társadalmi érvényesülés, önérték-maximalizálás és a figyelem értéke áll a középpontban.

A következőkben az érdekel bennünket, hogy a 21. századi általános célú infokommunikációs technológia miként alakítja át ezt a reklámjelenséget. Ahogyan a tranzakciókban általában, ezen a területen is számos új jelenségnek lehetünk tanúi:

- az utóbbi évtizedben több, korábban ismeretlen hirdetési csatorna és az információk elérésének számos új technikai lehetősége jelent meg (a közösségi médiától az okostelefonokig);

- gyors eltolódások tapasztalhatók a különféle hirdetési helyek, reklámelhelyezési felületek között az újabbak javára és a régiek rovására;

- úffajta információközvetítők jelennek meg a reklámok célba juttatására;

- megváltozott a reklámok jellege, tartalma: megjelentek például az úgynevezett inbound reklámok; a csupasz és direkt reklámozás rovására erősödik a más tartalmakkal (például oktatással, szórakoztatással) összekapcsolt reklám; 
- erősödik a személyre szabás: a reklámok címzettje egyre kevésbé a tömeg vagy valamely széles vásárlói réteg, hanem egyre inkább az egyén;

- legjobb reklámozó a vevő: a vevők nem csupán passzív befogadói a reklámoknak, hanem „résztvevők” is a reklámozási tevékenységben;

- a reklámok mind nagyobb mértékben kerülnek át a világhálóra; az Amazon. com bevételeinek 50 százaléka már a 90-es évek végén is a könyvkiadók hirdetéseiből származott.

\section{Átterelödés az internetre: keresők és blogok}

A korábban legnagyobb hatású marketingeszköznek tartott televíziós reklámblokkok egyre kevésbé érik el a céljukat. Az Egyesült Államokban a főműsoridős nézettségi arányok zuhannak, a nézők tévézés közben egyre kevésbé figyelnek a képernyőn futó műsorokra, igen nagy hányaduk például számítógépét, okostelefonját figyeli közben. Mindazonáltal a tévéreklámokra fordított kiadások az összes hirdetési kiadás 33,6 százalékát tették ki 2019-ben, és még mindig nőnek (2023-ra várhatóan 6,5 százalékkal). A mobilreklámokra fordított kiadások 2022 végéig lassuló ütemben 240 milliárd dollárra nőnek, dinamikájuk évi 10,4 százalék. A globális digitalizált hirdetési kiadások, a koronavírus-járvány miatti lassulás ellenére, 389 milliárd dollárra nőnek 2021 végére - 2019-hez képest évi átlagban 9,5 százalékkal (Guttmann [2020a], [2020b], [2020c]). Nincs kétségünk afelől, hogy a jövő, akárcsak az egyéb piaci tranzakciók esetében, a reklámoknál is a mobilmegoldásoké.

A cégek felismerik, hogy reklámüzeneteik célba juttatásához az internetes keresőre feltett reklámok alkalmasabbak a hagyományos tévéspotoknál. ${ }^{16} \mathrm{~A}$ digitális jellegü reklámüzenetekre fordított kiadások gyors növekedése tapasztalható az Egyesült Államokban, miközben a nyomtatott felületeken a kiadások mérséklődtek. Például a 2016-ot megelőző öt évben az egész reklámpiac mérete közel 10 százalékkal bővült. Ám eközben a nyomtatott reklámokra fordított kiadások körülbelül 12 százalékkal estek, és a digitális megoldásokra fordított kiadások mintegy 73 százalékkal nőttek (eMarketer [2019], Guttmann [2019a]). E tendencia folytatódása várható 2018 és 2023 között, amikor is a 2018-as majdnem 109 milliárd dollárról 2023-ra közel 202 milliárd dollárra nőhetnek, azaz 85 százalékkal bővülhetnek a digitális hirdetési kiadások (Guttmann [2019b]).

A hirdetési bevételek megoszlását tekintve, a legnagyobb rész a digitális hirdetéseket közlő piacvezetö társaságok közül a Google-nak jut (2. táblázat). Rögtön utána azonban más keresőket megelözve a Facebook, tehát egy közösségi oldal következik.

\footnotetext{
${ }^{16}$ A honlap egyre inkább kapuként szolgál a cég márkanevéhez, termékeihez és szolgáltatásaihoz. A jelenség bekerült a szótárba is a googled a company kifejezéssel, ami magyarra elég nehezen fordítható le, talán a vállalat "googlizálásának", azaz internetes tesztelésének nevezhetnénk. A keresési üzlet az internetes hirdetés leghatékonyabb formája (Economist [2004]).
} 
2. táblázat

A digitális hirdetéseket közlő piacvezető társaságok nettó digitális hirdetési bevételben való részesedése a teljes nettó hirdetési bevétel százalékában, 2011-2015

\begin{tabular}{lrrrrr}
\hline Társaság & 2011 & 2012 & 2013 & 2014 & 2015 \\
\hline Google & 13,5 & 15,1 & 17,6 & 20,7 & 24,6 \\
Facebook & 14,1 & 14,6 & 15,5 & 16,2 & 16,2 \\
Yahoo & 11,0 & 9,0 & 7.7 & 6,7 & 6,1 \\
Microsoft & 4,9 & 4,5 & 4,3 & 4,0 & 3,7 \\
AOL & 4,3 & 3,5 & 3,1 & 2,7 & 2,4 \\
Twitter & 1,1 & 1,7 & 2,7 & 3,6 & 4,2 \\
Teljes digitális hirdetési bevétel (milliárd dollár) & 12,33 & 14,98 & 17,67 & 20,73 & 23,87 \\
\hline
\end{tabular}

Megjegyzés: beleértve a laptopokon és asztali számítógépeken, valamint a mobiltelefonokon és táblagépeken feltűnő hirdetéseket. Az adatokat 2011-től az IAB/PwC-adatokból számították ki, beleértve a reklámcsík- (banner) hirdetéseket, az értéknövelt tartalmú (rich) médiát, a szponzorálást és a videót. Nettó bevételről van szó, miután a társaságok kifizették a hálón való forgalmazás diját (traffic acquisition costs, TAC) a partneroldalaknak.

Forrás: Gesenhues [2013].

Az internet egyik legújabb, viharos sebességgel terjedő hajtása a blog, azaz az internetes napló (Scott [2010]). Az online reklámozók szinte megjelenésükkel egy időben felfedezték a blogokban rejlö üzleti lehetőségeket. A vevőszerzési erőfeszítések legújabb célpontja az úgynevezett civil média, amely föként az internetes naplókban ölt testet. Üzleti szervezetek - például a PayPerPost, az About.com ${ }^{17}$ vagy a Blogvertise - specializálódnak a bloggerek és a hirdetők összekapcsolására. A reklámozó cégek (általában reklámügynökségek közbeiktatásával) fizetnek a bloggereknek azért, hogy népszerü blogjukon közzétegyék a hirdetésüket.

A reklámok, hirdetések magánéletbe való behatolására, a magánszféra és az üzlet összeolvadására, a határvonalak elmosódására érdekes példával szolgálhatnak a blogokra feltett hirdetések. A blogokra történő behatolás formái:

- a bannerek (szalaghirdetések),

- az úgynevezett kontextuális (vagy beágyazott) reklámtermékek,

- szponzorált posztok a közösségi médiában (influencer marketing),

- különleges egyedi szponzorálás stb.

A vállalatok érdeklődése egyre nő a blogok iránt - látogatottságuknak, népszerüségüknek köszönhetően. Az a tény, hogy a Pew Internet \& American Life Project felmérése szerint az amerikaiak mintegy 27 százaléka olvas blogokat, a hirdetők szemében rendkívül felértékeli ezt a médiumot (Rodgers [2005]). Mint minden hirdetési médiumnak, a blognak is megvan természetesen a maga hátránya.

\footnotetext{
${ }^{17}$ A feltételeket lásd a http://weblogs.about.com/od/monetizingablog/u/MonetizeABlog.htm\#s1 címen.
} 
A különleges „hirdetési helyek” közé sorolhatjuk a korábban már említett internetes szoftvereket, amelyeknek ingyenes verziói reklámokkal vannak tele. Ha a vevő fizet értük, akkor „megszabadul” a reklámtól. Számos játékapplikáció müködik így.

\section{Közösségi média}

A vevők elérésének új csatornái közül érdemes kiemelni a közösségi médiát. A közösségi oldalak jelenlegi és jövőbeli potenciálját jól érzékelteti a regisztráltak száma. 2020-ban 3,8 milliárd fö használt valamilyen közösségi hálózatot, míg 2014-ben még ennek csak kevesebb mint 50 százaléka, 1,85 milliárd fö; 2011-ben pedig csak 1,2 milliárd fö (a 2020. évinek kevesebb mint 32 százaléka). A közösségi hálózatok használatának az üteme látványosan nőtt az elmúlt évtizedben: 2011 és 2014 között több mint 54 százalékkal (az átlagos növekedési ütem évente 11 százalék), 2014 és 2020 között pedig valamivel több mint 205 százalékkal (az átlagos növekedési ütem évente 13 százalék). A világ lakossága 7,8 milliárd fö (urbanizáció 55 százalék), a mobileszközöket 5,2 milliárd fö használja (a penetráció 67 százalék), az internethasználók száma 4,54 milliárd fő (a penetráció 59 százalék), közösségi médiát használ 3,8 milliárd fö (a penetráció 49 százalék) (Digital 2020 [2020]).

A közösségi oldalak felhasználóinak száma dinamikusan nő, ezek az oldalak a potenciális vevők ideális elérési helyei a termékeiket reklámozni kívánók számára. Aligha meglepő, hogy a közösségi médiára szánt reklámkiadások is dinamikusan nőnek (5.ábra).

\section{5. ábra}

A közösségi médiára szánt reklámkiadások az Egyesült Államokban, 2011-2016

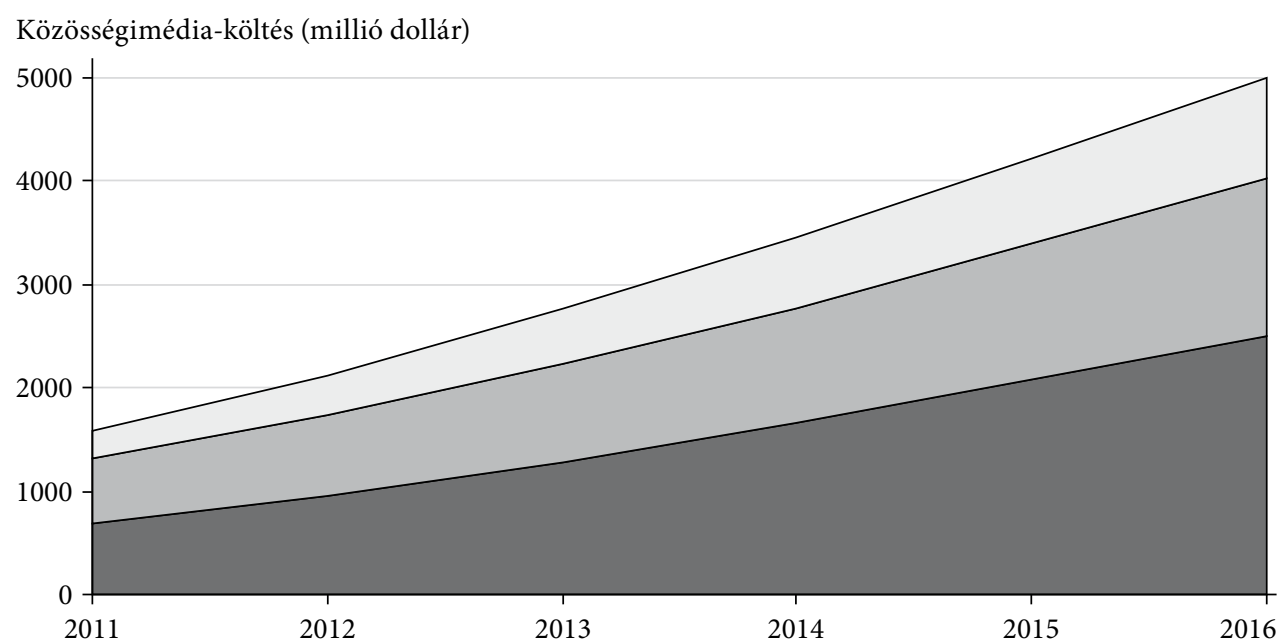

Közösségi médiához kapcsolódó menedzsmenttechnológiák

Közösségi médiához kapcsolódó ügynökségi díjak

Integrált kampányok a közösségi hálózatokon

Forrás: Scevak-VanBoskirk [2011]. 


\section{Új módszerek a vevők meghódításában és figyelmük fenntartásában}

A vevők/partnerek figyelmének a megragadásáért folyó éles verseny új és új megoldások bevetésére ösztönzi a szakembereket. Csak példaként, a tartalommarketingtől a vevők mozgósításán/bevonásán és a komarketingen át a hálózati hatások erősítéséig. Ezek tárgyalására itt nincs mód, de a „mobilizáció” tendenciájára és a perszonalizáció, a konkrét egyének felé fordulás irányzatára fontos röviden kitérni.

\section{A hirdetések „mobilizálása”}

Nemcsak a hirdetések közzétételének a helye, hanem a megjelenítésük technikai eszközei is változnak. Ahogy az $e$-kereskedelemböl lassanként $m$-kereskedelem lesz, az $e$-hirdetések is mindinkább $m$-hirdetésekre váltanak. A hirdetéseket egyre növekvő mértékben mobiltelefonon keresztül juttatják el a potenciális vevőkhöz. A mobileszközöknek mint a reklámokat célba juttató csatornáknak is egyre nő a jelentősége. A fogyasztók egyre nagyobb része e-mailjeit is mobilján olvassa. Míg 2011-ben csak kevesebb mint 30 százalékát nyitották meg az e-maileknek mobilon, addig ma a legtöbb felmérés 50 százalék körüli értéket jelez (Knotice [2012] ${ }^{18}$ és Campaign Monitor [2019]). ${ }^{19}$

Ez a trend lecsapódik a marketingkiadások struktúrájának a változásában is, hiszen az elörejelzések szerint a marketingre költött összegek növekedése 2007 és 2022 között a mobilmarketingnél a leglátványosabb, 179 millió dollárról várhatóan 247,51 milliárd (!) dollárra nő (Guttmann [2020b]). Ha ehhez még hozzávesszük, hogy az e-mailmarketing egyre növekvő része is tulajdonképpen mobileszközökön történik, akkor a mobil növekedése még látványosabb. A mobilmarketing súlya a legnagyobb a kereskedelem és a szolgáltatások területén (6. ábra).

Nemcsak a figyelem felkeltésének a csatornái, közvetítő közege változik meg radikálisan az infokommunikációs technológia határa, hanem a módszerei is.

\footnotetext{
${ }^{18}$ A Knotice nevü, ohiói székhelyű amerikai marketingszervezet a táblázatot 11 iparág és 976 millió e-mail vizsgálata alapján állította össze.

${ }^{19}$ Természetesen az átlagtól jelentős a \pm eltérés az életkor, a képzettség, a lokáció és a foglalkozás jellege szerint.
} 
6. ábra

Mobilmarketingre költött összegek világszerte, 2007-2022

Milliárd dollár

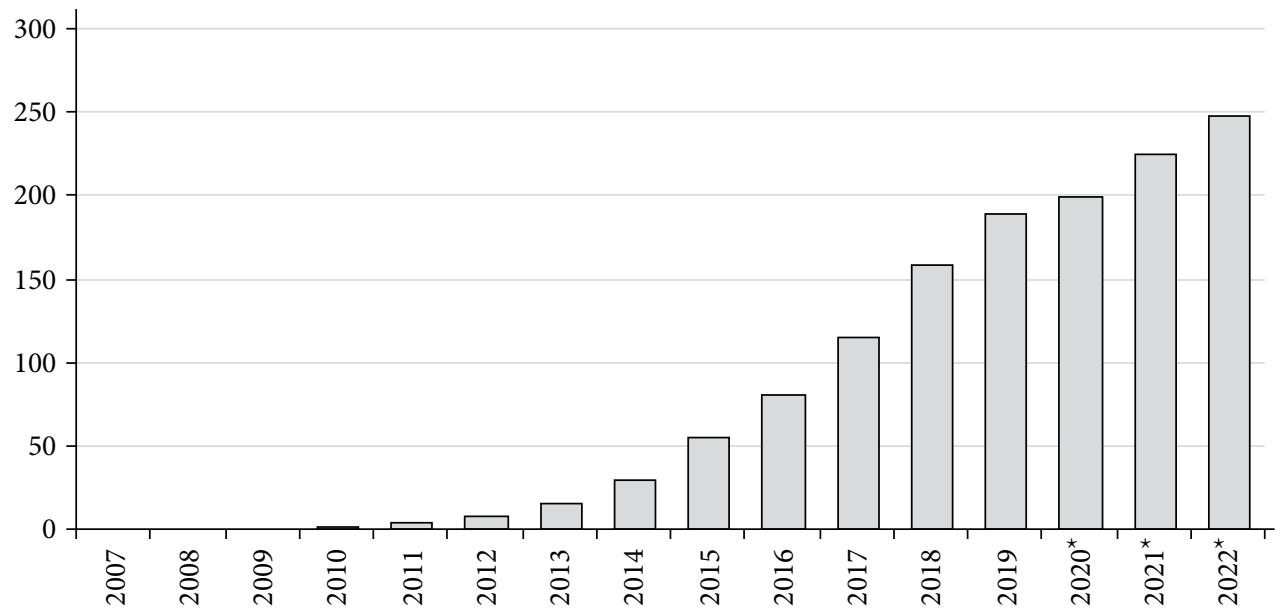

* Elörejelzés.

Forrás: Guttmann [2020b]

\section{Személyre szabás}

A személyre szabás filozófiája, amely áthatja az egész információgazdasági rendszert, lecsapódik a hirdetésekben is. Új módszereket kell kialakítani arra, hogy a hirdetésben közölt információ az egyénnek szóljon, az egyénre hasson, az egyént aktivizálja. A Kmart nevü kereskedelmi lánc számára a BlueLight nevü szolgáltató valósította meg a személyre szabás marketingstratégiáját.

A BlueLight által csak „ragadós tégláknak” (sticky bricks) nevezett marketingstratégia lényege, hogy a vásárlókban sokoldalú lojalitást építenek ki az eladó, adott esetben a Kmart iránt. Több mint 5 millió felhasználó regisztráltatta magát, ennek köszönhetően a BlueLight a negyedik legnagyobb ${ }^{20}$ internetes szolgáltató volt 2013-ban. A BlueLighton keresztül történő online vásárlás után a vevőknek speciális személyes ajánlatokat tettek, egyéni ízlésüknek megfelelöen. Az Amazon.comon lényegében hasonló rendszert látunk: a visszatérő vásárlót egy személyes ajánlati lista fogadja könyvekkel, CD-kkel. A különleges ajánlatok a vásárlókhoz e-mailen keresztül is eljuthatnak, és természetesen elérhetők az üzletekben is. A vevők reklamáció esetén visszavihetik a vásárolt termékeket a lakhelyük közelében levő Kmart üzletbe. Ennek a lehetőségnek a felkínálásakor kihasználják a cég legnagyobb versenyelőnyét, nevezetesen azt, hogy 2163 üzletet tart fenn, elszórva 50 államban. Az Egyesült Államok lakosságának mintegy 85 százaléka mindössze egy rövid autóutnyira lakik valamelyik Kmart-üzlettől, így az áruk visszavitelének a lehetősége csak még több potenciális vásárlót csalogat a Kmarthoz. Vannak széles körü akciók, amelyek minden vásárlóra kiter-

\footnotetext{
${ }^{20}$ A legnagyobbnak, az American Online-nak 30 millió feletti előfizetője van világszerte. (2013-as adat).
} 
jednek. Néhányan viszont az üzletekben levő terminálon ugyanazokkal a személyre szóló hirdetésekkel találkoznak, mint amelyek BlueLight-előfizetőként jutnának el hozzájuk. Ez az úgynevezett internetbefolyásolt értékesítés (web impacted retail) (Nolan [2001] 112. o.).

Vegyük észre, hogy az internetbefolyásolt értékesítés a klasszikus és az e-kereskedelem meglehetősen sikeres összekapcsolása. E megoldás ugyanakkor mind a vevői, mind az eladói oldalon egyszerre növeli meg a figyelemmel szembeni igényeket és befolyásolja a figyelmi kapacitások kihasználását. A sikeres példa ragadós. Klasszikus kereskedelmi vállalkozások sora veszi ma már igénybe a BlueLight-technikát, azaz kihasználja az internet adta előnyöket mind a klasszikus kereskedelmi forgalom bővítésére, mind pedig az individuális vásárlói profilok kialakítása révén a személyre szabás előnyei által generálható vásárlói keresleti többlet érdekében.

E folyamatok mögött az is meghúzódik, hogy a vevők úgy találják, a tradicionális kommunikációs gyakorlat, azaz a tömeghirdetések nagyon lassúak, ezért nem igazán alkalmasak az információgazdaság céljainak elérésére. A mai hirdetések többsége helyi jellegü, specifikus (helyi újságok, helyi rádió, helyi televízió) és nemzeti (a legtöbb magazin, a nemzeti rádió és televízió). Az internettel tehát belépnek a vásárlók a „direkt információ” korába, ahol megkeresik az adott weboldalt, és közvetlen megbeszélést folytatnak a termelőkkel a szükségleteikről.

Azt is látni kell ugyanakkor, hogy az átalakulás eredményeként születő új típusú reklámok a formálódó információgazdaság árnyoldalait is láthatóvá teszik. A vállalatok piaci expanziója nem áll meg az otthonok falai előtt, nem marad meg az utcán, az üzletekben és más közösségi tereken, hanem behatol a legintimebb magánszférába, a barátságok „kötőanyagává” vagy éppen kiüresítojévé válik. ${ }^{21} \mathrm{Az}$ internetes közösségépítés, amely eredetileg tisztán közösségépítésként indult, ma már sokszor csak az üzleti tevékenység meghosszabbítása. Miközben a tőke - mint a korábbiakban láthattuk - lazábbra engedi kapcsolatát a munkavállalókkal, igyekszik mind szorosabban befonni a fogyasztókat. Ebben már az információgazdaság egy újabb szerkezeti elemét, az összemosódást (blurring) fedezhetjük fel.

Összefoglalóan azt hangsúlyozzuk, hogy az információgazdaságban, az internet, a digitalizáció és a mobilizáció világában különös jelentőségre és szerepre tesz szert a figyelem. Ennek a jelenségnek az egyik fontos vetülete a vevőkért folytatott harc új és új formáinak a megjelenése, a vevők és az eladók közötti kommunikáció intenzívebbé, kiterjedtebbé és egyúttal személyre szabottabbá válása. A hirdetésekben is - akárcsak az eladóknak a vevők iránt tanúsított figyelmében, a vevőkkel való kapcsolat folyamatos ápolásában - világosan kirajzolódnak az információgazdaság általános tendenciái. Az egyoldalú kínálati nyomást kifejező reklámok helyett, amelyek mintegy „kinyilatkoztattak”, ezen a területen is tapasztalható az interaktivitás és a személyesség térhódítása, ugyanúgy, a hogyan a helyhez kötöttség oldása vagy a gyorsulás. Nem egymástól független változásokról van szó, az új jelenségek rendszerré állnak össze, amely merőben különbözik az indusztriális kapitalizmus rendszerétől.

\footnotetext{
${ }^{21}$ Mindenki átélt már hasonlót: barátja megjelenik otthonában, de nem azért, hogy a hogyléte felől érdeklődjön, hanem hogy Zepter edényt vagy életbiztosítást sózzon rá. Ez persze nemigen erősíti a barátságot.
} 


\section{Hivatkozások}

ArIELY, D. [2014]: Az ésszerütlenség nem várt előnyei. HVG, Budapest.

Becker, G. S.-Murphy, K. M. [1993]: A Simple Theory of Advertising as a Good or Bad. The Quarterly Journal of Economics, Vol. 180. No. 4. 941-964. o. https://doi. org/10.2307/2118455.

Belk, D.-Belk, P. [2020]: The Pharmaceutical Industry. Megjelent: Belk, D.: True Cost of Healthcare. https://truecostofhealthcare.org/the_pharmaceutical_industry/.

Bőgel György [2012]: Terepszemle. Tanulmányok és feljegyzések az infokommunikációs világról. Typotex Kiadó, Budapest.

Brennan, Z. [2019]: Do Biopharma Companies Really Spend More on Marketing Than R\&D? Regulatory Focus, július 24. https://www.raps.org/news-and-articles/news-articles/2019/7/ do-biopharma-companies-really-spend-more-on-market.

Campaign Monitor [2019]: 7 Stats That Will Make You Rethink Mobile Email. Campaign Monitor Blog, július, https://www.campaignmonitor.com/blog/email-marketing/ 2019/07/7-stats-that-will-make-you-rethink-mobile-email/.

Coursey, D. N. L.-MAson, C. F. [1987]: Investigations Concerning the Dynamics of Consumer Behavior in Uncertain Environments. Economic Inquiry, Vol. 25. No. 4. 549-564. o. https://doi.org/10.1111/j.1465-7295.1987.tb00760.x.

Davenport, H.-Beck, J. C. [2002]: The Attention Economy. Understanding the New Currency of Business. Harvard Business School Press, Boston.

Dennott, S. [2004]: Gone in 30 Seconds. Changing Technology and Viewing Habits Are Replacing the Old TV Spot with Longer (and Shorter) Ad Forms. Newsweek International Edition, Questia, február 23. https://www.questia.com/read/1G1-113539888/gone-in-30seconds-changing-technology-and-viewing.

Denzau, A.-North, D. [1994]: Shared Mental Models: Ideologies and Institutions. Kyklos, Vol. 47. No. 1.3-31. o.

Digital 2020 [2020]: Digital 2020 Global Overview Report. https://wearesocial.com/ blog/2020/01/digital-2020-3-8-billion-people-use-social-media.

DyвwAв, B. [2009]: Information Overload: Americans Consume 34 GB Of Data Daily. Mashable, december 9. https://mashable.com/2009/12/09/american-data-diet/?europe=true.

Economist [2004]: A Perfect Market. The Economist, május 15. https://www.economist.com/ special-report/2004/05/15/a-perfect-market.

EMARKeter Editors [2019]: US Digital Ad Spending Will Surpass Traditional in 2019. Insider Intelligence, eMarketer, február 19. https://www.emarketer.com/content/us-digital-adspending-will-surpass-traditional-in-2019.

Evans, D.-Hutley, R. [2010]: The Explosion of Data. How To Make Better Business Decisions by Turning "Infolution" into Knowledge. Cisco Internet Business Solutions Group (IBSG), San Jose, CA. https://www.cisco.com/c/dam/en_us/about/ac79/docs/pov/Data_Explosion_IBSG.pdf.

FALKINGER, J. [2008]: Limited Attention as a Scarce Resource in Information-Rich Economies. The Economic Journal, Vol. 118. No. 532. 1596-1620. o. https://doi.org/10.1111/j.14680297.2008.02182.x.

Festré, A.-Garrouste, P. [2015]: The 'Economics of Attention': A History of Economic Thought Perspective. Economia, Vol. 5. No. 1. 3-36. o. https://doi.org/10.4000/ oeconomia.1139. 
Fichter, K. [2001]: Ökonomie der Aufmerksamkeit. Zur Rolle von Aufmerksamkeit in der Medien- und Internetökonomie. Bordestep-Arbeitspapier, No. 1. Borderstep Institut für Innovation und Nachhaltigkeit, Berlin.

Franck, G. [1998]: Ökonomie der Aufmerksamkeit. Ein Entwurf. Verlag Carl Hanser, München.

Franck, G. [2019]: The economy of attention. Journal of Sociology, Vol. 55. No. 1. 8-19. o. https://doi.org/10.1177/1440783318811778.

Franklin Templeton Investments [2012a]: 2012 Franklin Templeton Global Investor Sentiment Survey designed in partnership. https:/www.franklintempleton.co.uk/down loadsServlet/?docid=h21w6qwo.

Franklin Templeton Investments [2012b]: Investors Should Beware the Role of "Availability Bias”. Business Insider, október 6. https://www.businessinsider.com/the-availabilitybias-is-driving-investor-decisions-2012-10.

Franklin Templeton Investments [2013]: Perception: What Investors Believe Happened. S\&P 500 Annual Returns vs. Percentage of Investors Who Said the Market Was Down or Flat? https://www.franklintempleton.com.br/content-global/campaigns/ttts/html/en_OS/ advisor/perception-vs-reality.html\#.

Gesenhues, A. [2013]: EMarketer: Google Takes Back Top Spot In 2012, Out-Selling Facebook In Digital Display Ads. EMarketer, Marketing Land, április 1. http://marketingland.com/ emarketer-google-wins-back-hold-top-rank-in-digital-marketing-revenue-38207.

Goldhaber, M. H. [1997a]: Attention Shoppers! The Currency of the New Economy Won't Be Money, But Attention. A Radical Theory of Value. Wired Magazine, Vol. 5. No. 12. 182-190. o.

Goldhaber, M. H. [1997b]: The Attention Economy and the Net. Draft version of a talk presented at the conference on „Economics of Digital Information”. Cambridge, MA, január 23-26. https://people.well.com/user/mgoldh/AtEcandNet.html.

Guttmann, A. [2019a]: Advertising spending in the U.S. 2015-2022. Statista, március 28. https://www.statista.com/statistics/272314/advertising-spending-in-the-us/.

Guttmann, A. [2019b]: Digital advertising spending in the U.S. 2018-2023. Statista, augusztus 9. https://www.statista.com/statistics/242552/digital-advertising-spending-in-the-us/.

Guttmann, A. [2020a]: Television advertising worldwide. Statista, szeptember 10. https:// www.statista.com/topics/5952/television-advertising-worldwide/.

Guttmann, A. [2020b]: Mobile advertising spendig worldwide 2007-2022. Statista, szeptember 29. https://www.statista.com/statistics/303817/mobile-internet-advertising-revenueworldwide/.

Guttmann, A. [2020c]: Digital advertising spending worldwide 2015 to 2022. Statista, november 17. https://www.statista.com/statistics/237974/online-advertising-spending-worldwide/.

Hickethier, K.-Bleicher, J. K. (szerk.) [2002]: Aufmerksamkeit, Medien und Ökonomie. Münster.

Kinsey, J. D.-Weaver, W. W. [2003]: Encyclopedia of Food and Culture. Megjelent: Katz, S. H.-Weaver, W. W. (szerk.)): Encyclopedia of Food and Culture.Vol. 1. Scribner, New York, 462-465. o.

Knotice [2012]: Knotice Releases Mobile Email Opens Report for Second Half of 2011. Cision, április 11. https://www.prnewswire.com/news-releases/knotice-releases-mobileemail-opens-report-for-second-half-of-2011-146979995.html.

Kornai JÁnos [2011]: Gondolatok a kapitalizmusról. Akadémiai Kiadó, Budapest. https:// doi.org/10.1556/9789630597357. 
Kraut, R. E.-Sunder, S.-Telang, R.-Morris, J. [2005]: Pricing Electronic Mail to Solve the Problem of Spam. Human-Computer Interaction, Vol. 20. No. 1. 195-223. o. https://doi. org/10.1207/s15327051hci2001\&2_7.

Krieken, R. van [2019]: Georg Franck's 'The Economy of Attention': Mental capitalism and the struggle for attention. Journal of Sociology, Vol. 55. No. 1. https://doi. org/10.1177/1440783318812111.

LANHAM, R. A. [2006]: The Economics of Attention: Style and Substance in the Age of Information. University of Chicago Press, Chicago.

Lundin, K. [2018]: 5 Reasons Why Your Business Is Losing Customers. Entrepereneur Europe, május 16. https://www.entrepreneur.com/article/313463.

Mandel, T.-Van Der Leun, G. [1996]: Rules of the Net: How to Live and Thrive in Cyberspace Once You've Finally Arrived. Hyperion Books, New York.

Manyika, J.-Chui, M.-Brown, B.-Bughin, J.-Dobbs, R.-Roxburgh, Ch.-Hung Byeres, A. [2011]: Big Data: The Next Frontier for Innovation, Competition and Productivity. McKinsey Global Institute (MGI) Executive Summary. McKinsey \& Company.

Markillie, P. [2004]: A Perfect Market. The Economist, május 15. 3-5. o. https://www. economist.com/special-report/2004/05/15/a-perfect-market.

Marr, B. [2018]: How Much Data Do We Create Every Day? Forbes, május 21. https://www. forbes.com/sites/bernardmarr/2018/05/21/how-much-data-do-we-create-every-day-themind-blowing-stats-everyone-should-read/?sh=360cee6460ba.

Négyesi Áron [2004]: Sniper Strategies in Online Auctions. Megjelent: Hámori BalázsCzeglédi Pál-Jankovics László-Sági Balázs (szerk.): Paradigm Shift. Information, Knowledge and Innovation in the New Economy. Debrecen, 133-139. o.

Nolan, C. [2001]: Attention KMART Shoppers... Ziff Davis Smart Business for the New Economy (Electronic Journal), február 1. 112. o.

Press, G. [2020]: 6 Predictions About Data In 2020 And The Coming Decade. Forbes, január 6. https://www.forbes.com/sites/gilpress/2020/01/06/6-predictions-about-data-in-2020and-the-coming-decade/?sh=26cc16404fc3.

Rajabzadeh, A.-Nejadirani, F.-Soroodian, R.-Kermani, R. A. [2011]: Informational Overload. Roots and Consequences. Australian Journal of Basic and Applied Sciences, Vol. 5. No. 12. 353-359. o.

Rodgers, Z. [2005]: Measuring Blog Marketing. ClickZ Network, január 12. http://www. clickz.com/clickz/news/1700563/measuring-blog-marketing.

Scevak N.-VAnBoskirk, S. [2011]: Forrester Research Social Media Forecast, 2011 To 2016 (US). Forecast View Spreadsheet, július 29. https://www.forrester.com/report/Forrester+ Research+Social+Media+Forecast+2011+To+2016+US/-/E-RES60578.

Sciтоvsкy TiвоR [1990]: Az örömtelen gazdaság. Gazdaságlélektani alapvetések. Közgazdasági és Jogi Könyvkiadó, Budapest.

ScotT, D. M. [2010]: The New Rules of Marketing and PR: How to Use Social Media, Blogs, News Releases, Online Video and Viral Markerting to Reach Buyers Directly. John Wiley \& Sons, Hoboken, NJ.

Shapiro, C.-VArian, H. R. [1999]: Information Rules: A Strategic Guide to the Network Economy. Harvard Business School Press, Boston.

Simon, H. A. [1971]: Designing Organizations for an Information-rich World. Megjelent: Greenberger, M. (szerk.): Computers, Communication, and the Public Interest. Johns Hopkins University Press, Baltimore, MD, 37-52. o. https://digitalcollections.library.cmu. edu/awweb/awarchive?type $=$ file\&item $=33748$. 
Simon, H. A. [1982]: Korlátozott racionalitás. Közgazdasági és Jogi Könyvkiadó, Budapest.

Thомas, G. [2003]: Umkämpfte Aufmerksamkeit Medienethische Erwägungen zu einer knappen kulturellen Ressource. Zeitschrift für Evangelische Ethik, Vol. 47. No. 1. 89-104. o. https://doi.org/10.14315/zee-2003-0114.

Tversky, A.-Kahneman, D. [1981]: The Framing of Decisions and the Psychology of Choice. Science, Vol. 211. No. 4481. 453-458. o. https://doi.org/10.1126/science.7455683.

WAters, R. [2011]: Technology: A binary goldmine. Financial Times, május 5. https://www. ft.com/content/1986d61e-7744-11e0-aed6-00144feabdc0.

Weber, A. [2002]: Managing the Marketing Budget in a Cost-constrained Environment. Industrial Marketing Management, Vol. 31. No. 8. 705-717. o.

Wilder-James, E. [2012]: What is big data? An introduction to the big data landscape. O’Reilly, január 11. https://www.oreilly.com/radar/what-is-big-data/.

\section{Kedves Szerző ink!}

Az MTA Könyvtár és Információs Központtal együttműködve cikkeinket ellátjuk a CrossRef-nél regisztrált DOI-azonosítóval. Ezért kérjük, hogy a Hivatkozásokban tüntessék fel a művek DOl-azonosítóját (természetesen sokszor előfordul, hogy nincs ilyen). A DOI a következő linkre kattintva kereshető meg: http://search.crossref.org.

Például:

Boldrin, M.-Montes, A. [2005]: The intergenerational state. Education and pensions. Review of Economic Studies, Vol. 72. No. 3. 651-664. o.

A hivatkozott tételt bemásoljuk a keresőmezőbe, a találati listából pedig kiválasztjuk a megfelelő tételnél lévő hivatkozást, és beszúrjuk a hivatkozás végére: BoldRIN, M.-Montes, A. [2005]: The intergenerational state. Education and pensions. Review of Economic Studies, Vol. 72. No. 3. 651-664. o. http://dx.doi.org/ 10.1111/j.1467-937x.2005.00346.x.

Ne feledkezzenek meg a beszúrt hivatkozás hiperhivatkozásként való megjelöléséről a kéziratban!

A CrossRef-nél regisztrált DOI növeli a cikkek láthatóságát, könnyíti az adott, kapott hivatkozások összeszámlálását! 